\title{
Genetic Diversity in Weeds
}

\author{
Claudete Aparecida Mangolin ${ }^{1}$, Rubem Silvério de Oliveira Junior ${ }^{2}$ \\ and Maria de Fátima P.S. Machado ${ }^{1^{*}}$ \\ ${ }^{1}$ Departamento de Biologia Celular e Genética; \\ ${ }^{2}$ Departamento de Agronomia, Universidade Estadual de Maringá, Maringá,PR,
} Brasil

\section{Introduction}

Weeds growing in cultivated areas are usually characterized as having high phenotype plasticity and genetic adaptability. They are frequently well-adapted to disturbance and often seed prolifically (Adahl et al., 2006). Thus, improving the current knowledge on the genetic diversity of weed populations is a challenge for management, primarily because this variability may be an important tool in determining the adoption and efficiency of weed control methods. Genetic markers may be important to improve current knowledge about important aspects of weeds, and may provide needed information to understand patterns of weed invasion, heritability of traits (e.g. herbicide resistance), taxonomic relationships, point of origin, and gene flow. Studies on genetic diversity both at population and species levels are important for weed management, and represent a source of information about genetic bottleneck effects, fitness, and the number of input events that contributed to a successful introduction (Goolsby et al., 2006; Hufbauer, 2004; Sterling et al., 2004). Improving the knowledge about genetics of weeds can provide vital information for the development of innovative control options (Slotta, 2008).

In natural habitats, plant populations often have greater genetic variability as compared to populations of exotic weed species, since very rarely all possible genotypes are introduced in a new environment. Thus, native weeds commonly represent major challenges for weed management programs, because of their wider genetic variability (Sterling et al., 2004). Assuming that the genetic variation among populations impacts the effectiveness of weed management tools, native weeds would represent the most difficult species to be controlled, as compared to exotic species. On the other hand, exotic species can prove way more aggressive in colonizing a habitat than natural weeds, since they might have no natural competitors or predators that control the population. Therefore, they can be as difficult to control as are the native species of weeds. Investigating the effectiveness of different weed management strategies in populations of native or exotic weeds may be important to provide information about the role of genetic variability on weed management success.

The magnitude of genetic variability may be estimated by using molecular or biochemical markers and studying nucleic acid or isozyme sequences. Isozyme markers have been used

* Corresponding Author 
to study accessions of Setaria glauca, S. geniculata and S. faberii, worldwide weeds of tropics and temperate regions (Wang et al., 1995). By elucidating the genetic diversity and genetic structure of populations, the authors found low genetic variability for populations of $S$. faberii, S. glauca, and S. geniculata, although there was a substantial genetic differentiation between S. glauca and S. geniculata. Native populations also exhibited higher genetic diversity than exotic species. Patterns of genetic organization in S. glauca and S. geniculata may have also been influenced by several factors, including genetic bottleneck effect associated to the founder effect, random genetic drift and natural selection (Wang et al., 1995).

The genetic variability among six accessions of Baccharis myriocephala was evaluated by multivariate methods using isozyme and morphological descriptors (Castro et al., 2002). As regards the isozyme analysis, only the esterase system provided satisfactory resolution and two groups were formed. Use of morphological descriptors at 145 days after transplantation provided an efficient method to discriminate four groups of accessions. Isozymes were used as genetic markers to discriminate these accessions in Baccharis myriocephala, allowing its use in the characterization of varieties to complement morphological characteristics.

The analysis of products of different loci in plant tissues of weeds may be useful to estimate the genetic variability within each population and among different populations (Park, 2004). In recent literature addressing the detection of polymorphic loci to estimate the genetic diversity in plants through biochemical markers, the esterase system has been usually and primarily adopted as a genetic-biochemical marker. Many studies (Mangolin et al., 1997; Resende et al., 2004; Souza et al., 2004; Pereira et al., 2001; Orasmo et al., 2007) have demonstrated that the $\alpha$ - and $\beta$-esterases isozymes are produced by several and different loci, that mostly show co-dominant inheritance, being, therefore, an enzyme system suitable to estimate the genetic diversity and to analyze the genetic structure of plant populations.

For weeds, the analysis of $\alpha$ - and $\beta$-esterases isozymes using polyacrylamide gel electrophoresis (PAGE) was first established by Frigo et al. (2009), and was considered effective to analyze the genetic diversity and structure of populations of wild poinsettia (Euphorbia heterophylla). Frequencies of allelic variants found in this study were estimated for Est-1, Est-2, Est-3, Est-4, Est-5, Est-6, and Est-7 loci, and the estimated proportion of polymorphic loci in populations was $87.5 \%$. The positive value of $F_{\text {IS }}(0.1248)$ indicated deficit of heterozygous or excess of homozygous plants. A relatively high level of differentiation was found among descendents of all 12 populations, indicating a reduced gene exchange among populations. Values of $F_{\mathrm{ST}}$ indicated that $16.63 \%$ of the total variance for allele frequency in populations of E. heterophylla occurred due to genetic differences among populations. Analysis of genetic diversity of 40 populations of E. heterophylla resistant to ALS herbicides growing in southern plateau of Brazil led to the conclusion that those populations present $60 \%$ of genetic variability. Such level of variability allowed grouping resistant plants in seven distinct groups (Winkler et al., 2003). In another study with different accessions of Euphorbia spp. from North America and Eurasia, the most divergent accession was the one collected in Austria, followed by accession from Italy and Russia. Accessions of E. heterophylla from USA were most intimately related to each other and also related to Russian accession (Nissen et al., 1992). A high degree of genetic variability was also described for the Euphorbia esula accession from USA (Rowe et al., 1997). The variability was attributed to multiple introductions of the species as well as to 
variability within native populations. For Bidens pilosa (beggartick) complex, a study on the genetic variability using 10 enzyme systems revealed 16 loci, but only three of them were polymorphic. For this complex, genetic diversity was low and characterized as being of 3.2\% (Grombone-Guaratini, 2005).

Factors that can lead to or accelerate the development of herbicide resistance include weed characteristics, chemical properties and cultural practices. One of the characteristics related to weeds that may favor the selection of individuals resistant to herbicides is the wide genetic variability, due to the increased probability to find within the population a resistance allele to the herbicide in use. This fact leads to the general understanding that prolific, high density weeds are more likely to develop selection for herbicide resistance (Vidal and Meroto Jr., 2001; Winkler et al., 2002).

So far, the main methods used for weed control include biological, chemical, physical and cultural approaches, but the achievements of weed management programs may also be associated to the genetic variability of those plants. Some important questions that will be addressed and hopefully answered by increasing knowledge of genetic variability of weeds are as follow: 1) Is the selection of weeds being imposed by management? 2) Is the intensity of selection pressure imposed by agricultural practices more powerful than that imposed by natural ecosystems? 3) Have weeds evolved and will keep evolving in response to agricultural management practices? 4) Is the success of management programs associated to genetic variability of weeds?

Chances are that colonizing species, including exotic weeds, will have low genetic variability, since they have been through a genetic bottleneck (that is, they have lost alleles) after their introduction. However, despite low genetic variability, many exotic weeds will successfully colonize new geographic areas. In this case, as long as weed species have high fitness and great potential for colonization, they will persist.

The wider genetic variability and the genetic structure of populations have an impact on success of weed management. To expand knowledge and provide answers to unsolved questions, much more is needed to know about genetic variability of these populations. To seek for those answers, our research group has developed standard procedures to analyze esterase, malate dehydrogenase, and acid phosphatase isozymes. These isozymes were used to estimate the genetic diversity and the level of differentiation among populations of Conyza spp. and Euphorbia heterophylla collected from farms with a history of frequent use of herbicides and from sites with little or no herbicide use. Findings in these studies will provide help to guide weed management and control strategies of these two important species, which have recently evolved resistance to herbicides under field conditions.

\section{Euphorbia heterophylla}

The Euphorbiaceae family (also known as spurge family) includes more than 290 genera and 7500 species distributed all over the world. Plants in this family are mostly herbs, but some may also be shrubs or trees. Euphorbia is one of the genera of the Euphorbioideae subfamily and includes around 2300 species of wide morphological variety. Most species of the spurge family are shrubs, growing between 40 and $60 \mathrm{~cm}$ in height. A milky sap that oozes from damaged stems and leaves (latex) is also characteristic of some subfamilies such as Euphorbioideae within the spurge family (Joly, 1998). 
Common names of Euphorbia heterophylla L. in Brazil include amendoim-bravo, leiteiro, parece-mas-não-é, flor-de-poeta, adeus-brasil, café-de-bispo, leiteira, café-do-diabo or mata-brasil (Suda, 2001). In English, it is usually referred as wild poinsettia, milkweed or mexican fire plant. In Brazil, it is widespread along Southern, Southeastern and Midwest regions and it is considered a native species in tropical and subtropical regions of the Americas (Cronquist, 1981). As a weed, it is a highly competitive, fast-growing, annual herb erect. Stems may be simple or branched; ovate to rhomboid leaves $(4-7 \mathrm{~cm}$ long by $1.5-3 \mathrm{~cm}$ wide) occur on stems or branches as opposite, alternate or whorled, $2-12 \mathrm{~cm}$ long, leaf stalk $0.5-4 \mathrm{~cm}$ long; flowers are male or female in terminal clusters, each flowerhead (cyathium) with a solitary terminal female flower surrounded by male flowers enclosed in a cup-shaped involucre with a solitary conspicuous gland; seeds with three longitudinal ridges. The fruits are small, segmented capsules and spread usually happens by seeds that are released explosively from ripe fruits (Cronquist, 1981; Kissmann and Groth, 1992) (Figure 1).
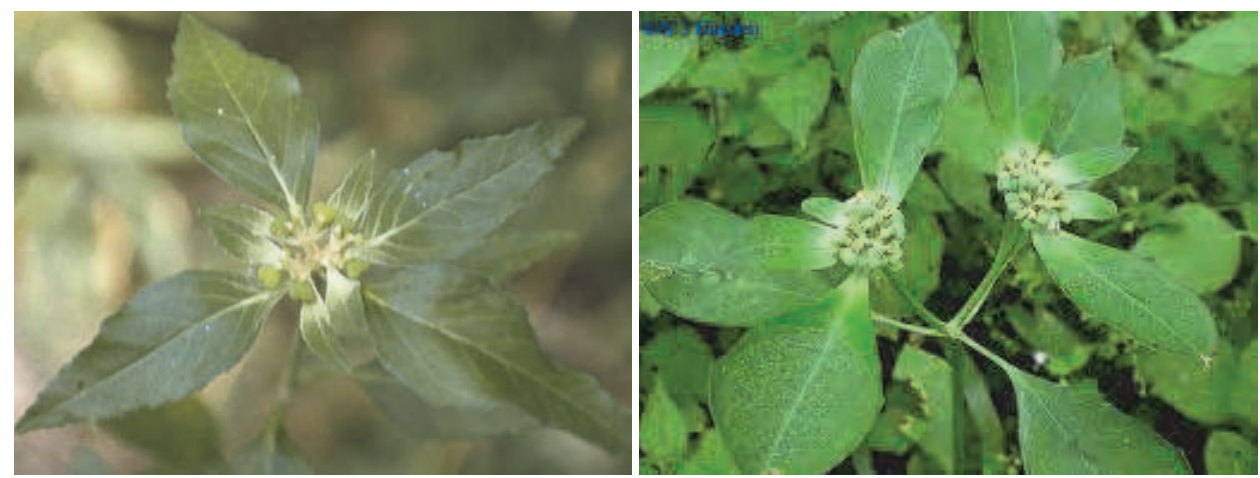

Fig. 1. Flowers of Euphorbia heterophylla in terminal clusters; each flower-head (cyathium) with a solitary terminal female flower surrounded by male flowers enclosed in a cup-shaped involucre with a solitary conspicuous gland.

Male flowers are constituted by one stamen, articulated in the pedicel, and the stamen surrounds the female flower (Kissmann and Groth, 1992). Reproduction of this species may be either by self or cross-fertilization (Cronquist, 1981; Barroso, 1984; Ingrouille, 1992) and is exclusively by seeds.

The fruits are small and contain trilocular segmented capsules, with one seed per locule. As fruit ripens, its color changes and at full maturity seeds are released explosively from ripe fruits, throwing seeds far away from mother-plants (Barroso, 1984). Seed is ovoid, with rough coat of variable color from light brown to almost black. Fruits are small, segmented capsules and have small bumps on the surface (mucilaginous cells); they have two cotyledons and dark coat (Cronquist, 1981; Barroso, 1984; Kissmann and Groth, 1992), and are produced in large quantities and with little to no dormancy. Causes of dormancy are not known, but light combined with alternating temperatures of $25-35^{\circ} \mathrm{C}$ stimulate germination (Kissmann and Groth, 1992). Seeds germinate easily from a 4-cm depth, showing germination asynchrony along time during soybean growth season in southern states of Brazil, such as Rio Grande do Sul and Paraná (Kissmann and Groth, 1992). 
E. heterophylla life cycle is short, allowing it to have two to three generations per year. The species develops well in almost all types of soil, but more prolific plants are found under fertile, well-drained soils. It is a representative of $\mathrm{C} 4$ photosynthetic pathway and the basic chromosome number is $2 n=32$. The species is allogamous and produces up to 3000 seeds per plant (Kismann and Groth, 1992).

The center of origin of E. heterophylla is the Brazil-Paraguay area (Kissmann and Groth, 1992), and it is currently widely distributed in south-central Brazil and neighboring countries. Former field studies carried out at the Rio Grande do Sul State central plateau demonstrated that $74 \%$ of soybean fields were infested with this species (Vidal and Winkler, 2002). At a density of 10 plants $\mathrm{m}^{-2}$, soybean yield was reduced by $7 \%$ by E. heterophylla competition during the whole crop cycle (Winkler et al., 2003; Chemale and Fleck, 1982). The presence of E. heterophylla at a 25 plants $\mathrm{m}^{-2}$ density caused a soybean yield daily loss of 5.15 $\mathrm{kg} \mathrm{ha}^{-1}$, whereas its absence provided a yield daily gain of $7.27 \mathrm{~kg} \mathrm{ha}^{-1}$. The critical period of interference for soybean in Brazil is considered to start as soon as 11 days after crop emergence (Meschede et al., 2002). Although reports of its relevance as a weed have been mostly related to soybeans, it is also an important competitor in other crops such as corn, peanuts, cotton, sugarcane, sorghum and beans.

\section{Euphorbia heterophylla and resistance to herbicides}

Among current agronomical techniques adopted to maximize crop growth and yield, weed management is considered one of the most influential on soybean grain yield. Weed management programs are set to minimize the effects of interference imposed by undesirable plants; this is important to maximize crop yield and also to reduce costs associated to crop production (Pitelli, 1985; Burnside, 1992).

The frequent use of a particular herbicide or of herbicides with the same mechanism of action may result in high selection pressure. Under high selection pressure the susceptible plants are killed while herbicide-resistant plants survive to reproduce without competition from susceptible plants, increasing, therefore, their frequency in the population (Ponchio, 1997; Mattielo et al., 1999).

Herbicide resistance is, by definition, the inherited ability of a plant to survive and reproduce following exposure to a dose of herbicide that would normally be lethal to the wild type. Resistance occurrence was hypothesized by Harper (1956) and documented by the first time in 1957 (Hilton, 1957; Switzer, 1957). Cases of herbicide resistance have been found in Brazil since 1996, and an average of one new case per year has been described so far (Winkler and Vidal, 2004).

In Brazil, the greatest concern about weed resistance is related to E. heterophylla, since its center of origin is located in Brazil-Paraguay region (Kissmann and Groth, 1992). It is usually found in high densities in field crops and imposes great impact to national agriculture. The most common herbicide alternatives in non transgenic crops include acetolactate synthase (ALS) and protoporphyrinogen oxidase (PROTOX) inhibitors (Vidal and Merotto Jr., 2001). Over the last decade, ALS-resistant biotypes have been identified in states such as Rio Grande do Sul, Paraná, São Paulo, Mato Grosso do Sul, Mato Grosso, Bahia, Tocantins and Minas Gerais, and in neighbor countries like Paraguay (Gazziero et al., 1998; Vidal and Winkler, 2002; Heap, 2010). Previous work has demonstrated that resistance 
to ALS herbicides is nuclear and dominant in E. heterophylla and that resistance is coded by a single dominant gene (Vargas et al., 2007).

According to the assumptions postulated by Winkler et al. (2003), soybean seeds commercialized in Rio Grande do Sul were all from the same commercial source and, therefore, seeds from weeds that are usually found in this crop may have spread geographically. Both species, soybean and wild poinsettia, would have evolved in a parallel process along the last years, favoring the selection of resistant biotypes to ALS-inhibiting herbicides in soybean fields, due to the intensive use of such mechanism of action. Weed resistance to these herbicides has already been described for six weeds in Brazil. The probability of selecting E. heterophylla biotypes with multiple resistance increases in the same order of magnitude as other herbicides with the same mechanism of action are used. Studies conducted by Trezzi et al. (2005) in southern states from Brazil (Paraná and Santa Catarina) have confirmed the presence of E. heterophylla biotypes with multiple resistance both to ALS and PROTOX inhibitor herbicides. In 2006, multiple resistance to ALS and EPSPs inhibitors was also reported (Vidal et al., 2007; Trezzi et al., 2009).

Weeds have a background of genetic diversity that gives them the ability to adapt to many different environments. The natural genetic diversity of weeds favors the selection of individuals resistant to herbicides most likely due to the highest probability of finding alleles that provide resistance to that particular herbicide (Winkler et al., 2003). Many studies have demonstrated that agronomic practices such as soybean mono cropping as well as the frequent and intensive use of herbicides with the same mechanism of action increase the selection pressure for resistant biotypes under such systems (Owen, 2001).

Several important points related to weed characteristics, herbicide properties, and cultural practices have been highlighted as key factors to explain the rapid occurrence and spread of weed resistance to herbicides (Vidal and Merotto, 1999). As concerned to weeds, annual growth habit, high seed production, relatively rapid turnover of the seed bank due to high percentage of seed germination each year (i.e., little seed dormancy), several reproductive generations in each growing season, extreme susceptibility to a particular herbicide (also called hypersensitivity of weeds to a particular herbicide) and the initial frequency of a resistant biotype in the population. Characteristics related to herbicides include a single site of action, dose violation (i.e. use of low or very high doses in relation to the optimum rates prescribed for a specific crop and situation), broad spectrum of weed control, frequency of use and long residual activity in soil. Cultural practices that may contribute in selecting for resistance include monocrop farming, reduced soil cultivation or zero tillage systems, failure to eliminate weeds that escape control by herbicides and use of a single herbicide or combinations that have same the mechanism of action in every season persistently.

\section{Genetic diversity in Euphorbia heterophylla}

Frigo et al. (2009) employed a non-denaturing PAGE system to identify polymorphism in $\alpha-\mathrm{e}$ $\beta$-esterases loci in leaf tissues of E. heterophylla from seeds of 12 populations collected in states of Paraná and Mato Grosso - Brazil (Figure 2) to analyze the genetic diversity and structure of populations. Eight clearly defined loci were detected by this method (Figure 3 ). The $\alpha$-preferential esterases, $\beta$-preferential esterases, and $\alpha / \beta$-esterases were numbered in sequence, starting from the anode, according to their decreasing negative charge. The 
esterase with the slowest migration was named as Est-8 (Figure 3). These results confirmed a previous hypothesis that PAGE may be a powerful procedure for analysis of $\alpha / \beta$-esterases isozymes from leaf tissues of wild poinsettia plants. Eight loci for isoesterases were simultaneously and clearly evident in the same electrophoresis, that is, using only one enzymatic system. Isozyme studies in other Euphorbia species have revealed only 11 loci from analysis of eight enzymatic systems (Park, 2004). The analysis of different enzymatic systems generally requires higher cost and time investments. Thus, $\alpha$ - and $\beta$-esterase isozymes analysis in PAGE system may be used in further studies to detect genetic diversity in other Euphorbia species

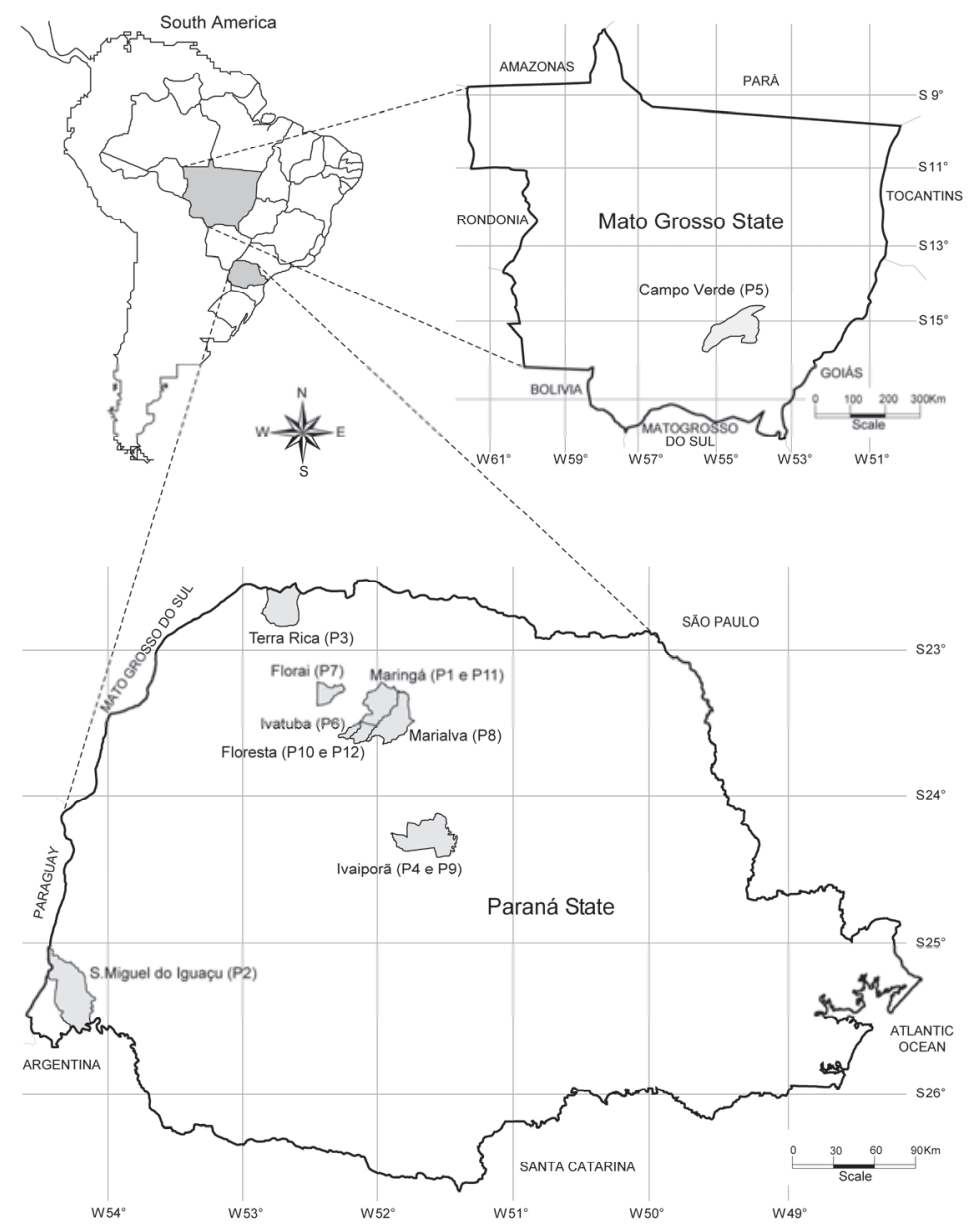

Fig. 2. Localities where seeds of wild poinsettia were collected at Mato Grosso, Brazil (MT) and Paraná, Brazil (PR) states: P1 and P11 (Maringá, PR), P2 (São Miguel do Iguaçu, PR), P3 (Terra Rica, PR), P4 and P9 (Ivaiporã, PR), P5 (Campo Verde, MT), P6 (Ivatuba, PR), P7 (Floraí, PR), P8 (Marialva, PR), P10 and P12 (Floresta, PR) populations. Source: Frigo et al. (2009). 
High and low genetic diversity levels have been reported in different populations of wild poinsettia by DNA fragment analysis as molecular markers (Vasconcelos et al., 2000; Winkler et al., 2003). Deploying $\alpha$ - and $\beta$-esterase polymorphisms in the PAGE system (Frigo et al., 2009) indicates that genetic diversity of wild poinsettia has higher mean values for grades of genetic variation (number of alleles per locus, proportion of polymorphic loci, observed and expected proportion of heterozygous loci) when compared to other Euphorbia species (Park, 2004).

The genetic variation in wild poinsettia is nearly as high as the genetic variability in Euphorbia ebracteolata, a widespread species (Park et al., 1999). The proportion of polymorphic loci in 12 wild poinsettia populations is much higher than the mean proportion value $(31 \%)$ reported for dicotyledons (Hamrick et al., 1979) and also for 16 species of Euphorbia (reviewed comparisons in Park, 2004).

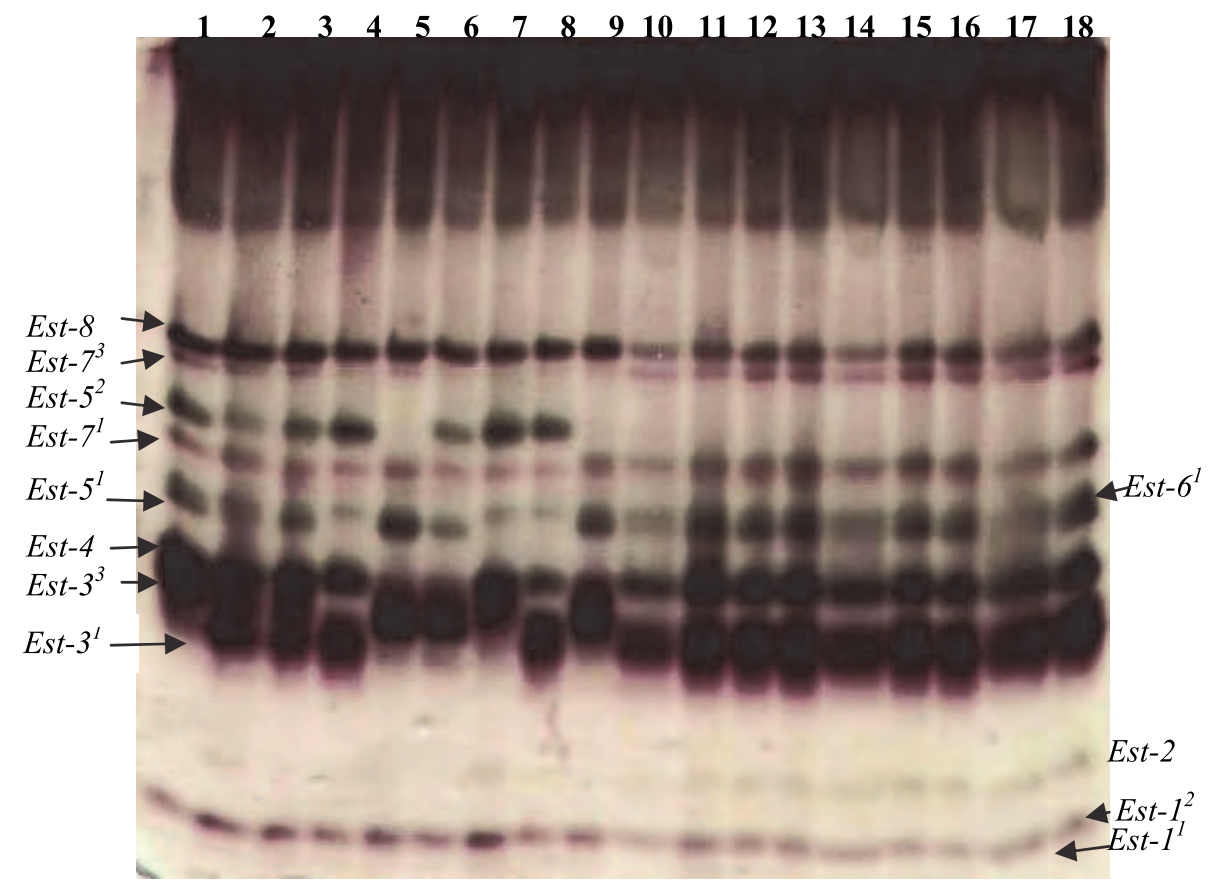

Fig. 3. Polymorphism of $\alpha$ - and $\beta$-esterases detected in eight loci of wild poinsettia plant descendants from 12 populations. Source: Frigo et al. (2009).

On the other hand, high and low values for observed $\left(\mathrm{H}_{\mathrm{o}}\right)$ or expected $\left(\mathrm{H}_{\mathrm{e}}\right)$ proportion of heterozygous loci in descendants from 12 different wild poinsettia populations sustain our preliminary hypothesis that wild poinsettia populations are genetically structured. Differential allele frequencies and proportions of heterozygous loci in different populations determined genetic divergence between the 12 populations $\left(\mathrm{F}_{\mathrm{ST}}=0.1663\right)$. According to Wright (1978), $\mathrm{F}_{\mathrm{ST}}$ values between 0.15 and 0.25 indicate high interpopulational divergence level, or high genetic differentiation level between populations. A highest level of genetic differentiation between populations $\left(\mathrm{F}_{\mathrm{ST}}>0.25\right)$ has been described in 12 out of the 16 
different Euphorbia species analyzed by Park (2004). The establishment of isolation and structuring mechanisms in populations has been reported in Euphorbia nicaeensis as a consequence of the inflorescence-architecture variability (Al-Samman et al., 2001). Substantial differences in the amount of genetic variation between different populations may indicate limited spatial dispersal or recent reduction in genetic variation caused by human action (Allendorf and Luikart, 2007).

Both limited spatial dispersal and populations frequently disturbed by human interference may determine high levels of spatial differentiation within wild poinsettia species. The explosive seed dispersal as a primary form of seed dispersal in Euphorbia species (Narbona et al., 2005) may explain the highly genetically structured populations. The seed dispersal of Euphorbia species may also occur by the activity of different ant species. In fact, the mean distance of seed dispersal has been positively correlated with size and species of ants (Gómez and Espadaler, 1998). Additionally, small-scale disturbances such as constant use of herbicides may create increased spatial heterogeneity. High selection pressure adopted in conventional weed management has caused selection of resistant biotypes (Holt and LeBaron, 1990) and may have determined highly structured populations within species.

High selection pressure imposed by the frequent use of herbicides in populations of $E$. heterophylla has not been detected through data obtained from $\alpha$ - and $\beta$-esterases. Parallel analysis comparing wild poinsettia plant descendants from seeds collected in organic culture of soybean (not exposed to herbicides) and plant descendants from seeds obtained in soybean culture frequently exposed to herbicides showed low genetic differentiation $\left(\mathrm{F}_{\mathrm{ST}}=0.03\right)$. Similarity between plants of E. heterophylla from organic and nonorganic fields was high $(I=0.9621)$ (Table 1$)$. However, the mean observed and expected heterozygosity was higher in wild poinsettia plants from organic crops $(\mathrm{Ho}=0.3526 ; \mathrm{He}=0.3980)$ than in plants from nonorganic crops $(\mathrm{Ho}=0.2569 ; \mathrm{He}=0.3641)$. A comparison of organic and nonorganic populations suggests that frequent herbicide exposure may lead to increased homozygosity.

The heterozygous deficiencies in 12 populations of wild poinsettia may be evident by the positive value of $\mathrm{F}_{\mathrm{IS}}\left(\mathrm{F}_{\mathrm{IS}}=0.1248\right)$. Positive $\mathrm{F}_{\mathrm{IS}}$ value indicates heterozygous deficit $(12.48 \%)$ or excess of homozygous plants, which could be the result of human selection pressure (frequent herbicide application) in soybean areas and/or the result of self pollination. In consonance with the significant $\mathrm{F}_{\mathrm{IT}}$ value $\left(\mathrm{F}_{\mathrm{IT}}=0.2703\right)$, overall inbreeding or nonrandomized breeding did play a major role in shaping the population's genetic structure. Increased homozygosity in wild poinsettia populations is important, because it leads toward a great number of deleterious recessive alleles in inbred plants, with a subsequent lowering of their fitness. Reduced heterozygosity reduces the fitness of inbred individuals at loci in which the heterozygous entities have a relative advantage over homozygous specimens (Allendorf and Luikart, 2007). Alternatively, a high number of heterozygous plants in populations of wild poinsettia may result in differential reactions and prevent uniform plant responses. High heterozygosity would indicate that the plant population has probably a substantial amount of adaptive genetic variations to escape the effects of a control agent.

The level of interpopulational genetic divergence in wild poinsettia species is revealed in the dendrogram through the genetic identity values (I) of 12 populations. Results in the dendrogram provide evidence that genetic divergence is independent of geographic 
distance (Figure 4). Lack of concordance between the geographic-distribution pattern and genetic identity for descendants from 12 populations may also be the result of the differential selection pressure or of the heterogeneity of environmental factors. Major understanding of the meaning of identity values could lead to important evidence related to differential tolerance to herbicides in field conditions and to development and spread of resistance. This in turn could lead to development of more effective policies of wild poinsettia control. For populations with higher identity values it may be possible to adopt similar strategies and processes for their control.

In subsequent studies carried out in our laboratory, the polymorphism for the $\alpha$ - and $\beta$ esterases loci of E. heterophylla plants from three distinct populations (organic population, herbicide-susceptible and herbicide-resistant populations) was evaluated in order to characterize diversity and genetic differentiation among these populations. The proportion of esterases polymorphic loci was $85.71 \%$. Allelic frequencies were analyzed for Est-1, Est-3, Est-4, Est-5, Est-6, Est-7, and Est-8 loci (unpublished results).

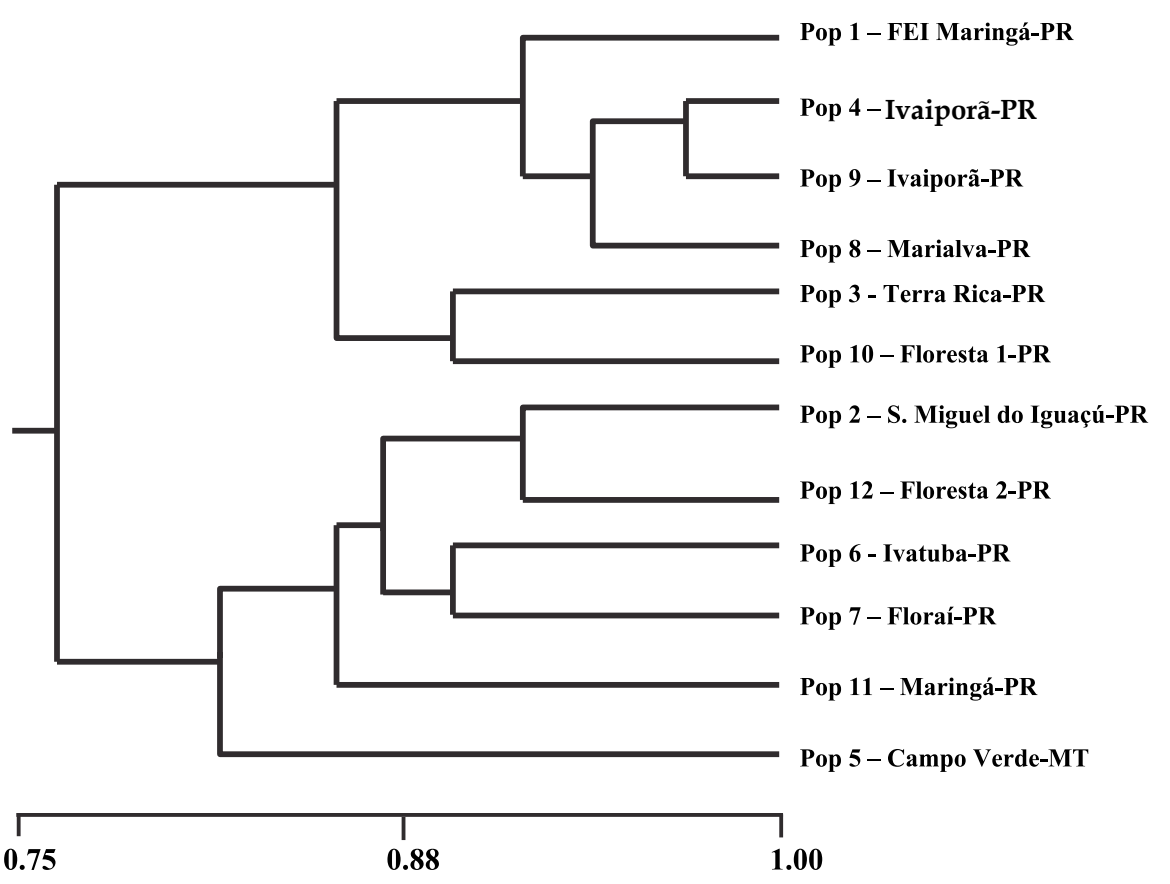

Fig. 4. The dendrogram represents the relationship between the plant descendants from 12 populations of wild poinsettia based on UPGMA cluster analysis of the allele polymorphism at Est-1, Est-3, Est-4, Est-5, Est-6, and Est-7 loci, by Jaccard's similarity coefficient.

As seen in Table 1, exclusive alleles and alleles with different frequencies were found for the three populations, suggesting that these enzymes may be involved with the differential metabolism of herbicides. Two alleles were detected in tissues from leaves of plants from organic and herbicide-resistant populations for Est-1, Est-4 and Est-5 loci. Locus Est-4 had 
three alleles in the susceptible population and the allele Est-43 has a low frequency in population (0.0014). For Est-3, Est-6 and Est-7 loci, three alleles were found for the three populations in this study (Table 1). The EST-2 esterase encoded by the locus Est-2 was found in $71.39 \%$ of plants of E. heterophylla and was absent in $28.61 \%$ of plants. In the research carried out by Frigo et al. (2009), EST-2 was not found for 100\% of herbicide-resistant plants analyzed (Figure 5), suggesting that this enzyme may be also involved with the differential herbicide metabolism.

\begin{tabular}{lccccccc}
\hline Locus & Est-1 & Est-3 & Est-4 & Est-5 & Est-6 & Est-7 & Est-8 \\
\hline \multicolumn{7}{l}{ Alleles } & \multicolumn{7}{c}{} & & & \\
\hline \multicolumn{7}{l}{ Organic population } \\
\hline $\mathbf{1}$ & 0.4454 & 0.4055 & 0.2143 & 0.7815 & 0.6324 & 0.6681 & 1.0000 \\
$\mathbf{2}$ & 0.5546 & 0.3613 & 0.7857 & 0.2185 & 0.3487 & 0.0021 & \\
$\mathbf{3}$ & 0.2332 & & & 0.0189 & 0.3298 & \\
\hline \multicolumn{7}{l}{ Herbicide-susceptible population } \\
\hline $\mathbf{1}$ & 0.6320 & 0.4105 & 0.1832 & 0.5289 & 0.8416 & 06956 & 1.0000 \\
$\mathbf{2}$ & 0.3680 & 0.4270 & 0.8154 & 0.4711 & 0.1556 & 0.0110 & \\
$\mathbf{3}$ & 0.1625 & 0.0014 & & 0.0028 & 0.2934 & \\
\hline \multicolumn{7}{l}{ Herbicide-resistant population } \\
\hline $\mathbf{1}$ & 0.3467 & 0.4315 & 0.7200 & 0.9667 & 0.6333 & 0.0533 & 1.0000 \\
$\mathbf{2}$ & 0.6533 & 0.5342 & 0.2800 & 0.033 & 0.3267 & 0.7333 & \\
$\mathbf{3}$ & 0.0342 & & & 0.0400 & 0.2133 & \\
\hline
\end{tabular}

Table 1. Allelic frequencies for Est-1, Est-3, Est-4, Est-5, Est-6, Est-7, and Est-8 loci observed in E. heterophylla from organic, herbicide-susceptible and herbicide-resistant populations.

A moderate level of genetic differentiation $\left(\mathrm{F}_{\mathrm{ST}}=0.1410\right)$ was found for all three populations, suggesting a reduced genetic exchange between them $\left(\mathrm{N}_{\mathrm{m}}=1.5231\right)$. High selection pressure imposed by the use of herbicides on E. heterophylla populations has been detected in data from $\alpha$ - and $\beta$-esterases. Similarity between plants of $E$. heterophylla from organic and herbicide-susceptible populations was high $(\mathrm{I}=0.9670)$, however, the mean observed and expected heterozygosity was higher in wild poinsettia plants from organic crops $\left(\mathrm{H}_{\mathrm{o}}=\right.$ $\left.0.3529 ; \mathrm{H}_{\mathrm{e}}=0.3923\right)$ than in plants from nonorganic crops $\left(\mathrm{H}_{\mathrm{o}}=0.2597 ; \mathrm{H}_{\mathrm{e}}=0.3693\right)$, and the lowest values of heterozigosity were found for the herbicide-resistant population $\left(\mathrm{H}_{\mathrm{o}}=\right.$ 0.2070; $\mathrm{H}_{\mathrm{e}}=0.3360$ ). A comparison of organic and herbicide-susceptible populations suggests that frequent herbicide exposure may lead to decreased heterozygosity and that the selection process of resistant biotypes further reduces heterozigosity. Because of the difference in allele frequency and heterozigosity, the three populations formed a group consisting of organic and herbicide-susceptible demonstrating greater similarity between them, while the herbicide-resistant population was isolated from this group, being the most divergent.

The dendrogram based on the genetic distances calculated by the UPGMA method (Figure 6), provided evidences of a group constituted by herbicide-susceptible and organic populations, demonstrating that these two populations present greater similarity, while the herbicide-resistant population was isolated from the other two populations. As regards the other two populations in this study, descendants of herbicide-resistant population had the 
highest level of differentiation observed. Nei's identity values (I) ranged from 0.7623 (descendants from herbicide-susceptible and herbicide-resistant populations) and 0.9670 (descendants from herbicide-susceptible and organic populations).

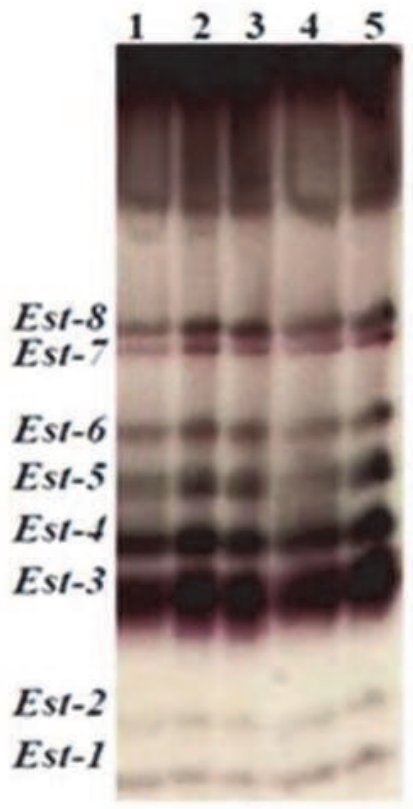

A

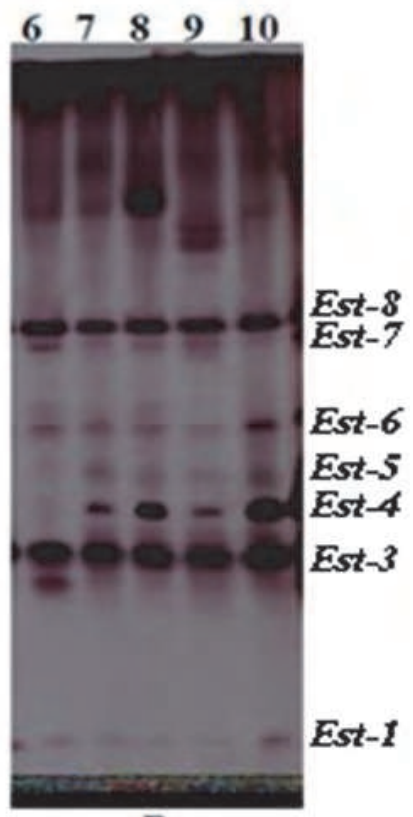

B

Fig. 5. Polymorphism of a- and $\beta$-esterases detected in plants of Euphorbia heterophylla descending from herbicide-susceptible (samples 1-5; gel A) and herbicide-resistant (samples 6-10; gel B). Gel A, samples from plants susceptible to ALS inhibitor herbicides, where Esterase-2 is present. Gel B, samples from ALS-resistant plants, where Esterase-2 is absent.

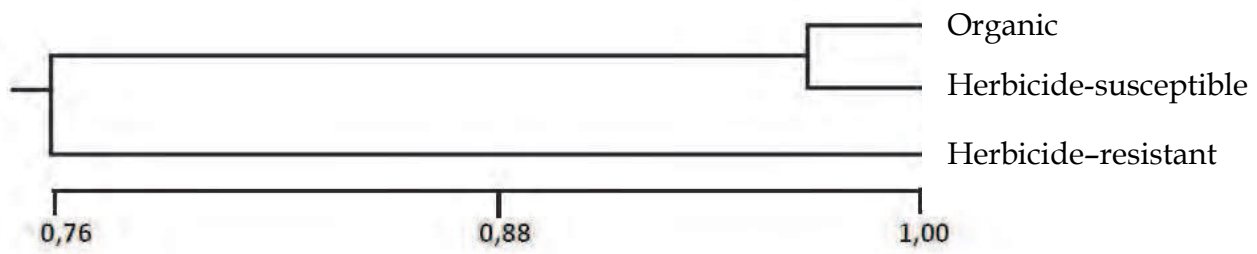

Fig. 6. Dendrogram representing the relationship between plants from organic, herbicidesusceptible and herbicide-resistant populations of Euphorbia heterophylla, based on similarity measure by UPGMA and cluster analysis for the alleles polymorfism from Est-1, Est-3, Est4, Est-5, Est-6, and Est-7 loci by Jaccard's similarity coefficient. 
Data from the studies evaluating a- and $\beta$-esterases provide evidences that populations of $E$. heterophylla have been under high selection pressure imposed by herbicide use. This has been verified by the differentiation between organic, herbicide-susceptible and herbicideresistant populations. Exclusive alleles and different frequencies for alleles in different loci of esterases found for the three populations suggest that these enzymes may be involved with differential metabolism of herbicides. Frequent use of a single herbicide or mechanism of action may exert a high selection pressure, reducing the susceptible populations, and, therefore, resulting in herbicide-resistant biotypes dominance, which already were found in natural populations, but in very low frequencies.

\section{Biology and ecophysiology of Conyza spp.}

The genus Conyza includes around 50 species, distributed all over the world (Kissmann and Groth, 1999). The species that stand out by their negative effects are Conyza bonariensis (L.) (fleabane, hairy fleabane) and Conyza canadensis (L.) (horseweed, marestail); both from Asteraceae family. The first is native to South America and abundant in Argentina, Uruguay, Paraguay and Brazil. In Brazil, its dispersion is more evident in South, Southeast and Midwest regions. It can also be found in coffee plantations in Colombia and Venezuela (Kissmann and Groth, 1999). Conyza canadensis, however, is native to North America (Frankton and Mulligan, 1987) and is one of the most widely distributed species globally (Thebaud and Abbott, 1995). It can be predominately found in Northern hemisphere temperate regions (Holm et al., 1997) and in subtropical regions of Southern hemisphere (Kissmann and Groth, 1999). C. canadensis is also present in Canada (Rouleau and Lamoureus, 1992), Western Europe (Thebaud and Abbott, 1995), Japan and Australia (Holm et al., 1997).

Propagation of both Conyza bonariensis and C. canadensis occurs through the seed only. The fruit is an achene with pappus, a simple one-seed fruit which has an apical structure of radiating fine light bristles (pappus) that serves as a means for seed dispersion by wind (Andersen, 1993), as well as by water (Lazaroto et al., 2008). Both Conyza species are selfcompatible and seem not to be pollinated by insects (Thebaud et al., 1996), although insect visits to open flowers of C. canadensis have been reported (Smisek, 1995).

Seeds are able to disperse by wind in distances over $100 \mathrm{~m}$ (Dauer et al., 2006). The average number of seeds found in C. canadensis and C. bonariensis ranges from 60 to 70 per achene (Smisek, 1995; Thebaud and Abbott, 1995) and from 190 to 550 per capitulum (Wu and Walker, 2004), respectively. C. canadensis densities of 10 plants $\mathrm{m}^{-2}$ growing in areas with no soil disturbance may produce as much as 200,000 seeds per plant (Bhowmik and Bekech, 1993). About $80 \%$ of them germinate next to mother-plants (Loux et al., 2004). With increasing densities, the number of flowering plants, the individual plant size and the number of seeds per plant decreases, but the global seed production per area remains very similar (Lazaroto et al., 2008).

Conyza seeds have no dormancy and germinate when ever favorable conditions of temperature and moisture are present ( $\mathrm{Wu}$ and Walker, 2004). Minimum temperature required for germination of C. canadensis was estimated in $13{ }^{\circ} \mathrm{C}$ (Steinmaus et al., 2000). Seeds from both $C$. canadensis and $C$. bonariensis germinate after exposition to temperatures between 10 and $25{ }^{\circ} \mathrm{C}$ (Zinzolker et al., 1985). In a study carried out in Australia, the 
optimum temperature for $\mathrm{C}$. bonariensis was $20{ }^{\circ} \mathrm{C}$, but minimum and maximum temperatures were estimated in $4.2^{\circ} \mathrm{C}$ and $35^{\circ} \mathrm{C}$ (Rollin and Tan, 2004).

Germination of $C$. canadensis seeds was higher during a period of light, but under lab conditions, these seeds also germinate either under no light or when submitted to alternate periods of light/dark (13/11 h) (Nandula et al., 2006). Aggregation of mulching as soil covers such as those propitiated by no tillage cropping systems may delay or prevent germination, allowing the crop to establish and suppress later fluxes of weeds that eventually will emerge (Lazaroto et al., 2008). Germination of C. canadensis seeds occurs preferentially in neutral to alkaline soils (Nandula et al., 2006). Therefore, soil liming should be planned and balanced to meet the crop needs of crops and not to promote favorable conditions to Conyza germination (Lazarotto et al., 2008). Conyza is also able to grow and reproduce under more limited soil resources (rough, stony areas) (Hanf, 1983), as well as flat, poorly drained areas, provided that there is no flooding (Smith and Moss, 1998).

Conyza canadensis is an annual or biennial species, depending on environmental conditions (Regehr and Bazzaz, 1979; Holm et al., 1997) and C. bonariensis is considered a typical annual (Kissmann and Groth, 1999). Studies in Australia demonstrated that plants emerge throughout the year, but maximum emergences occur in spring (Walker et al., 2004). Other studies have shown that Conyza is able to grow under a different set of climate types, but $C$. canadensis is rare under tropical conditions (Holm et al., 1997). In Canada, seed production and invading potential of Conyza as weed tend to be limited by latitude $52^{\circ} \mathrm{N}$ (Archibold, 1981). However, the two species of Conyza are tolerant to water stress conditions and use of irrigation is considered as an alternative to improve crop competitive ability against those weeds (Lazaroto et al., 2008).

\section{Management and herbicide resistance in Conyza species}

Both species Conyza bonariensis and C. canadensis are typical colonizers of abandoned areas, perennial and annual crops (soybeans, maize, cotton and wheat) (Thebaud and Abbott, 1995). Bruce and Kells (1990) demonstrated that the interference imposed by C. canadensis decreased soybean grain yield in $83 \%$ under no tillage conditions and weed densities around 150 plants $\mathrm{m}^{-2}$. Leroux et al. (1996) also demonstrated the effects of Conyza spp. in other crops such as onions and carrots, concluding that, in carrots, negative effects on crop harvest may be even more important than those found in crop yield. In Indiana (USA), Conyza infestations have been detected in about $63 \%$ of soybean areas cropped with soybeans for two consecutive years, in $51 \%$ of soybean areas with no crop rotation and in $47 \%$ of areas cultivated under soybean/corn rotations (Barnes et al., 2004). The inclusion of barley as a successional winter crop decreased C. canadensis populations in onion and carrots over the next summer (Leroux et al., 1996).

In Brazil, Conyza most prolific growth usually is found between winter crops harvest and summer crops sowing. Farmers have related poor control of Conyza with herbicides, especially those used for burndown prior to summer crops. Problems are mostly related to tolerance of adult plants to herbicides and also to resistance to glyphosate. In several field experiments carried out in the last years, we found that a fall application (usually one to two weeks after corn harvest in July/August) including tank mixtures of burndown herbicides and residual herbicides provide an excellent alternative for these areas. Residual herbicides 
added to these treatments improve control of emerged Conyza and provide residual control, so that at the point that next crop is about to be sowed, seed bank is adequately controlled or, when emerged, is still within a range of size $(\leq 10 \mathrm{~cm})$ that permits control with a regular burndown treatment (Oliveira Jr. et al., 2010).

Increases in soil disturbance reduce the densities of $C$. canadensis by $50 \%$ or more (Buhler and Owen, 1997). Seedlings of C. canadensis were detected in $61 \%$ of the crops that were not submitted to soil tillage, as compared to $24 \%$ under minimum soil tillage (Barnes et al., 2004). Thus, as survival rate is drastically reduced when these species are submitted to soil tillage, this has been a strategy to limit infestation in agricultural areas. The impediment to periodical soil tillage, like that imposed by no-tillage cropping areas, and the fact that under that cropping system the seeds of weeds are deposited in the soil surface or buried very shallow may be used as management tools to obtain a more uniform emergence of these plants in the field. Uniform emergence of weeds favor the efficiency of herbicides and tend to allow the use of non chemical alternatives of weed control, like mowing (Lazaroto et al., 2008).

Therefore, weed management practices as regards the Conyza species require the combination of multiple actions like increased intensity of soil management, adoption of routine crop rotations and cultural strategies (Lazaroto et al., 2008). In addition, the correct identification of Conyza species is important so that a suitable control method may be chosen.

The frequent use of a particular herbicide or of herbicides with the same mechanism of action in Conyza species may also result in high selection pressure. Glyphosate has been safely used for over 40 years in weed management. It is considered as a non-selective herbicide and is a very useful tool to promote soil protection by plant residues that are obtained from natural vegetation or a cover crop cultivated during the intercropping season in no-tillage areas. The growing dependence and overreliance on glyphosate to control weeds is a major concern for the maintenance of long-term viability of such valuable tool in weed managements, since the repeated use of one single herbicide molecule may select preexisting weed resistant biotypes, leading to increased densities of these biotypes in field (Powles et al., 1994). In general, species or biotypes of a species best adapted to a particular practice are selected and multiply rapidly (Holt and Lebaron, 1990). Evidences suggest that emergence of herbicide resistance in a plant population is due to the selection of preexisting resistant genotypes, which, because of the selection pressure exerted by repeated applications of a single herbicide, find conditions for multiplication (Betts et al., 1992).

Weed resistance to herbicides is not a new phenomenon. Plants of field bindweed (Convolvulus arvensis) resistant to glyphosate were identified in Indiana (USA) in the mid80 's in fields that had been sprayed repeatedly with glyphosate (Degennaro and Weller, 1984). However, weed resistance to glyphosate has become a major concern a few years after the release of the first Roundup Ready ${ }^{\circledR}$ soybean varieties in USA in 1996. Species that are currently considered as of greatest concern include those from the genus Conyza. The first reported case of glyphosate-resistant Conyza was found in Delaware (USA) in 2000 (Van Gessel, 2001).

Currently, Conyza resistant biotypes are distributed in over 20 U.S. states and in over 40 countries worldwide (Heap, 2010; Alcorta et al., 2011). In Brazil, the first sites of resistance 
were reported in Rio Grande do Sul in 2005, and thereafter these biotypes have rapidly dispersed in all southern states and, more recently, in Midwest and Southeast. All sites of reported detections of glyphosate-resistant Conyza spp. share the frequent use of this herbicide in weed control, little or no use of alternative herbicides that provide adequate control of Conyza spp., and long-term, no-till agricultural practices (Loux et al., 2009).

Resistance of Conyza spp. in relation to other herbicides has also been previously described. In 1980, Japanese scientists detected a resistant biotype of C. canadensis to the herbicide paraquat (Heap, 2010). Increased activity of detoxification enzymes such as superoxide dismutase or the compartimentalization of herbicide molecules at cellular organelles were related to the mechanism of resistance to paraquat (Ye et al., 2000). In Hungary, herbicideresistant populations of Conyza were simultaneously found for paraquat and atrazine (Lehoczki et al., 1984). In Israel and U.S. populations resistant to atrazine and chlorsulfuron (a ALS inhibitor) were also found (Heap, 2010).

Among the recommended measures to manage weed resistance to herbicides, the frequent monitoring of crops in field is essential, in order to identify eventual suspected plants, which should be systematically eliminated (Lazaroto et al., 2008).

\section{Genetic diversity in Conyza bonariensis and $C$. canadensis}

To estimate the level of genetic diversity and the level of differentiation among populations of Conyza bonariensis and C. canadensis, we have developed routine lab procedures to analyze esterase isozymes as well as malate dehydrogenase and acid phosphatase. We assume that this information may serve as a guideline for weed management of both species in view of the growing concern related to the spread of cases of resistance to herbicides.
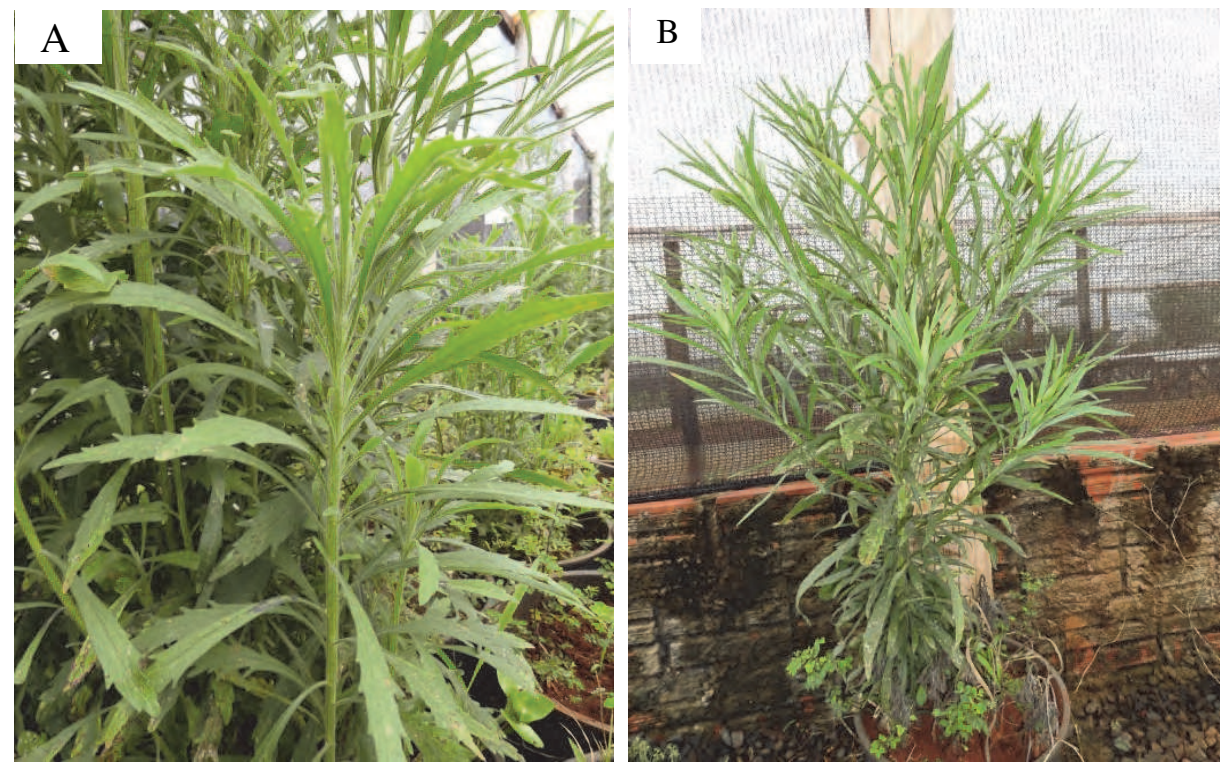

Fig. 7. Plants of Conyza bonariensis (A) and C. canadensis (B) used for analyze isozymes esterase, malate dehydrogenase and acid phosphatase. 
For analyze esterase isozymes (EST; EC 3.1.1._), malate dehydrogenase (MDH; EC 1.1.1.37) and acid phosphatase (ACP; EC 3.1.3.2) leaves of plants of $C$. bonariensis e C. canadensis were used (Figure 7). Leaf fragments $(200 \mathrm{mg})$ were homogenized with $60 \mu \mathrm{L}$ of a extraction solution prepared with phosphate buffer $1.0 \mathrm{M}$, pH 7.0 containing PVP-40 5\%, EDTA 1.0 $\mathrm{mM}, 0.5 \% \beta$-mercaptoetanol, and glicerol $10 \%$; extraction was performed in an ice bath using $2.0 \mathrm{~mL}$ microcentrifuge tubes. After homogenization, samples were centrifuged (centrifuge Juan $23 \mathrm{MRi}$, at 14,000 rpm - 48,200 g) for 30 minutes, at $4{ }^{\circ} \mathrm{C}$, and the supernatant $(50 \mu \mathrm{L})$ of each sample was used in electrophoresis.

Electrophoresis and $\alpha$ - and $\beta$-esterase identification was previously established by Frigo et al. (2009). To analyze enzymes malate dehydrogenase and acid phosphatase, after centrifugation supernatants were absorbed in strips of paper (Whatman $n^{\circ} 3 ; 5 \times 6 \mathrm{~mm}$ ), and these were vertically inserted into $16 \%$ starch gel, following the protocols described by Machado et al. (1993). Visualization (staining procedures) and identification of the malate dehydrogenase and acid phosphatases isozymes were also performed according to the protocols described by Machado et al. (1993).

Analysis of esterase isozymes from plant leaves of Conyza, through the non-denaturing PAGE method and using as substrates $\alpha$-naphthyl acetate and $\beta$-naphthyl acetate disclosed seven esterase loci clearly defined. The $\alpha / \beta$-esterases were listed starting from anode as EST-1 and following the order of decreasing negative charges. The slowest-migration esterase was named as EST-7 (Figure 8).

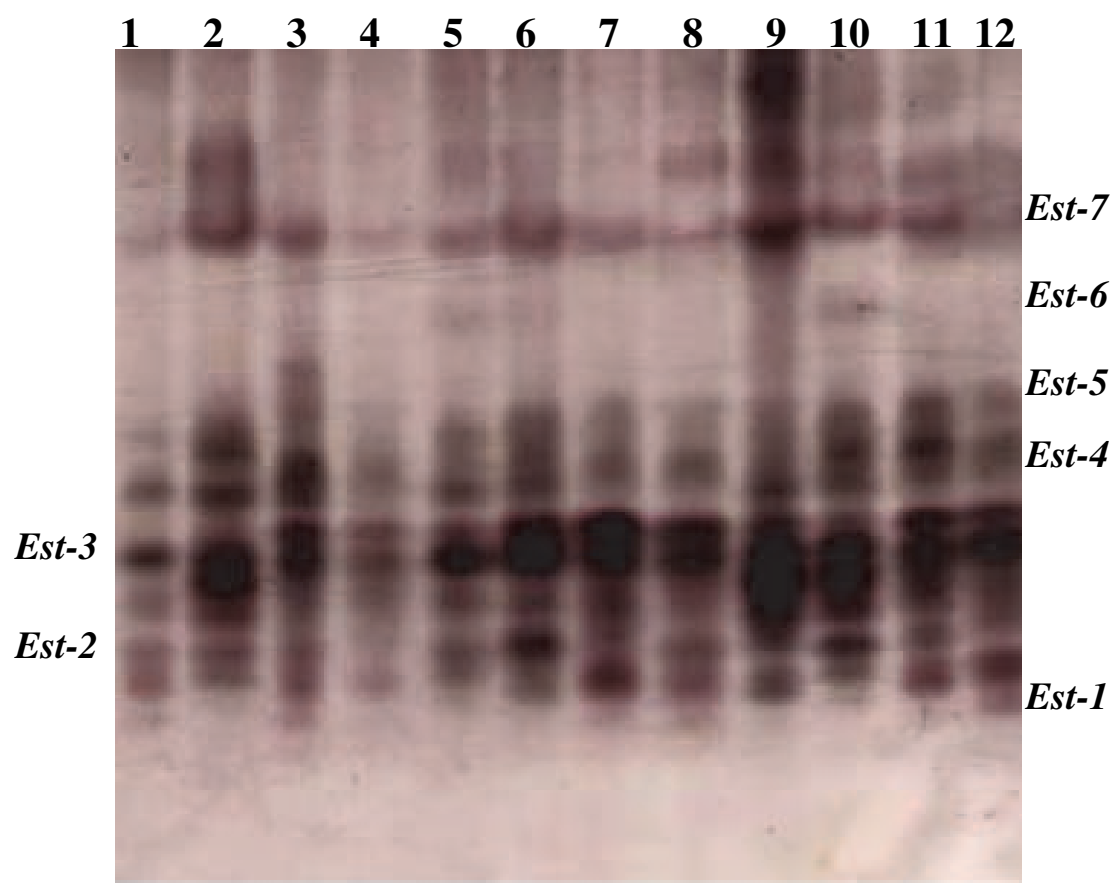

Fig. 8. Polymorphism of a- and $\beta$-esterases generated by loci Est-1, Est-2, Est-3, Est-4 and Est-5 detected in 12 plants of Conyza canadensis. 
Electrophoresis for malate dehydrogenase in starch gel demonstrated the presence of three different groups of malate dehydrogenase isozymes: the microbodies $\mathrm{MDH}(\mathrm{mbMDH})$, mitochondrial $\mathrm{MDH}(\mathrm{mtMDH})$, and cytosol or soluble $\mathrm{MDH}(\mathrm{sMDH})$ (Figure 8). Four $\mathrm{mbMDH}$ isozymes were evident (mbMDH-1, $\mathrm{mbMDH}-2, \mathrm{mbMDH}-3$, and $\mathrm{mbMDH}-4)$ at the $m b M d h$ locus; two other loci were evident for mtMDH isozymes ( $m t M d h-1$ and $m t M d h-2$ ) and another two loci for sMDH isozymes (sMdh-1 and $s M d h-2)$ (Figure 9). Due to the complex structural organization of these enzymes, which includes the ability to produce heterodimers between products from alleles of the $m t M d h$ and $s M d h$ loci, studies related to genetic diversity were only performed for the analysis of the $m b M d h$ locus. At the $m b M d h$ locus the presence of four alleles was evident (Figure 9).

For acid phosphatase isozymes, two loci (Acp-1 e Acp-2) were evident, but only the Acp-2 locus was analyzed, with four alleles for ACP-21, ACP-2 $2^{2}$ ACP-2 $2^{3}$ and ACP-2 $2^{4}$ isozymes (Figure 10).

Considering the three enzymatic systems, 14 loci were detected; from those, five that code for esterases were analyzed, as well as one locus coding for malate dehydrogenase and one locus for acid phosphatase, totalizing seven loci.

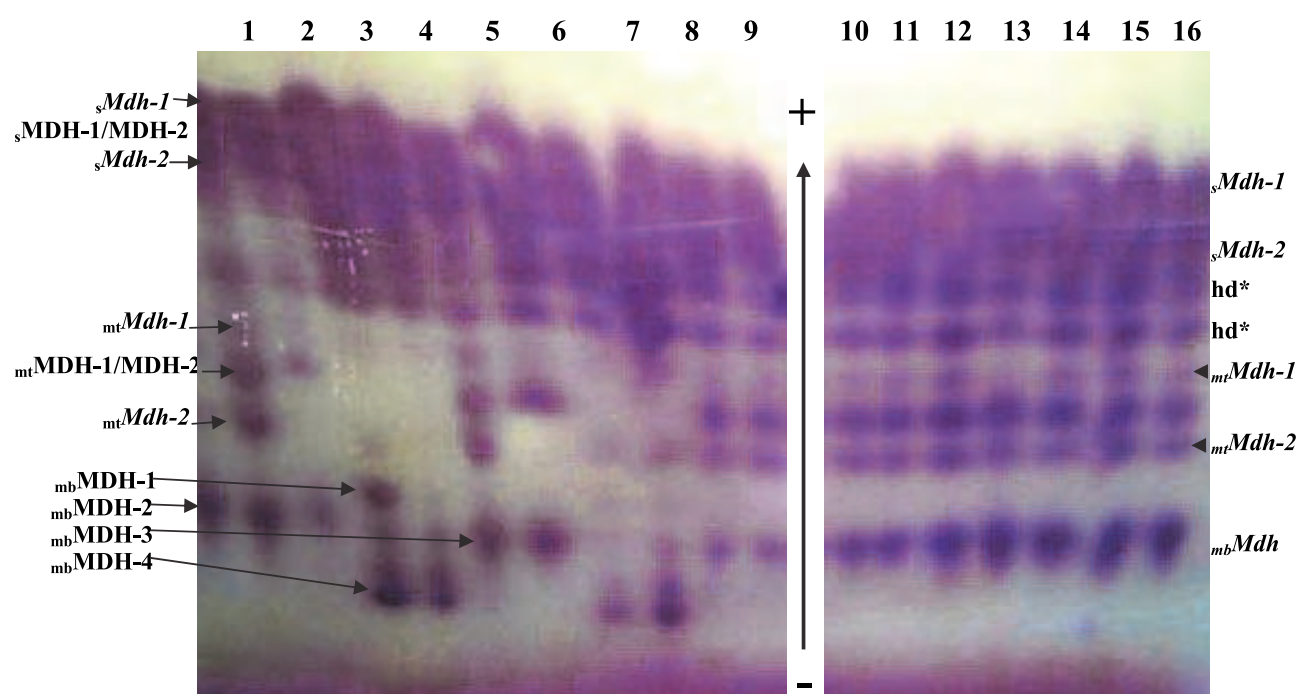

Fig. 9. Malate dehydrogenase from plants of Conyza canadensis (1-7) and C. bonariensis (8-16). Polymorphism for ${ }_{m b} M d h$ locus showing the four isozymes coded by their alleles (mbMDH-1, ${ }_{\mathrm{mb}} \mathrm{MDH}-2,{ }_{\mathrm{mb}} \mathrm{MDH}-3$, and $\left.{ }_{\mathrm{mb}} \mathrm{MDH}-4\right)$. Evidence of two loci ( ${ }_{m t} M d h-1$ and $\left.{ }_{m t} M d h-2\right)$ for mitochondrial MDH and two loci $\left({ }_{s} M d h-1\right.$ and $\left.{ }_{s} M d h-2\right)$ for the soluble $\mathrm{MDH}$ isozyme. The ${ }_{\mathrm{mt}} \mathrm{MDH}-1 / \mathrm{MDH}-2$ is the heterodimer between the product of the loci ${ }_{\mathrm{mt}} M d h-1$ and ${ }_{\mathrm{mt}} M d h-2$; ${ }_{s} \mathrm{MDH}-1 / \mathrm{MDH}-2$ is the heterodimer between the product of the ${ }_{\mathrm{s}} M d h-1$ and ${ }_{\mathrm{s}} M d h-2$ loci; hd* are heterodimers between the products of the loci ${ }_{m t} M d h-2$ and ${ }_{s} M d h-1$ and loci ${ }_{m t} M d h-1$ and ${ }_{s} M d h-1$. 
The genetic diversity found in our studies with $C$. bonariensis and $C$. canadensis based on $\mathrm{MDH}, \mathrm{ACP}$ and $\mathrm{a}-/ \beta$-esterases can be considered high, since polymorphism was detected for 7 out of 14 loci analyzed (50\%). That value may still be underestimated, because the polymorphism for the loci of the soluble and mitochondrial malate dehydrogenase, as well as for the Acp-1 locus, was not reported here. Hence the proportion of polymorphism for $C$. bonariensis and C. canadensis is much higher than mean values reported for dicotyledons (31\%) (Hamrick et al., 1979) and also for other weed species such as Euphorbia (Park, 2004; Frigo et al. 2009).

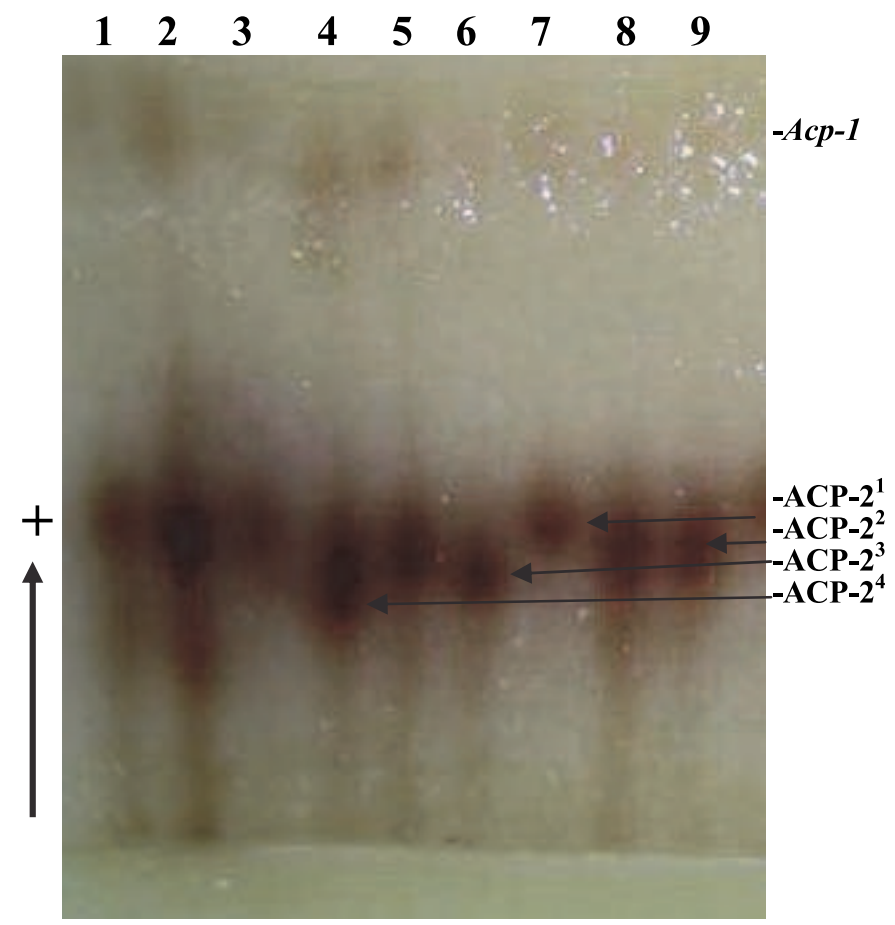

Fig. 10. Polymorphism of the acid phosphatase isozymes produced by locus Acp-2 coding for isozymes $\mathrm{ACP}-2^{1}, \mathrm{ACP}-2^{2}, \mathrm{ACP}-2^{3}$ and $\mathrm{ACP}-2^{4}$. Samples from 1 to 9 are Conyza bonariensis plants.

Observed heterozygosity $\left(\mathrm{H}_{\mathrm{o}}\right)$ for a- and $\beta$-esterases from $C$. canadensis and $C$. bonariensis was 0.4310 and 0.4293 , respectively; these values are lower than values for expected mean heterozygosity $\left(\mathrm{H}_{\mathrm{e}}\right)$, which was found to be 0.5125 and 0.4978 . The deficit of heterozygotes was higher when plants of Conyza were evaluated for the mbMdh and Acp-2 loci. Observed heterozygosity $\left(\mathrm{H}_{\mathrm{o}}\right)$ for $C$. canadensis was 0.4410 compared to an expected value $\left(\mathrm{H}_{\mathrm{e}}\right)$ of 0.6699. For C. bonariensis, the observed mean heterozygosity was 0.4333 compared to an expected value of 0.6149 .

For all 14 tests performed to analyze the Hardy-Weinberg equilibrium in both populations, equilibrium was found in only six of them $(42.86 \%)$. The lack of equilibrium for the analyzed loci is result of a deficit of heterozygous individuals. The fixation index $\left(\mathrm{F}_{\mathrm{IS}}\right)$ was positive for 
the Est-1, Est-2, Est-4, mbMdh and Acp-2 loci. For both populations, the $\mathrm{H}_{\mathrm{o}}$ was lower than expected, indicating the lack of heterozygous plants in populations of Conyza.

A low level of genetic differentiation was found for the two populations of Conyza, both when $\alpha-$ and $\beta$-esterase $\left(\mathrm{F}_{\mathrm{ST}}=0.0137\right)$, and malate dehydrogenase and acid phosphatase isozymes $\left(\mathrm{F}_{\mathrm{ST}}=0.0239\right)$ were evaluated. According to Wright $(1978)$, values of $\mathrm{F}_{\mathrm{ST}}<0.05$ indicate a low genetic differentiation between populations. That finding suggests an extensive genetic exchange $\left(\mathrm{N}_{\mathrm{m}}\right)$ between populations of $C$. canadensis and $C$. bonariensis, which was estimated to be of 18.008 and 10.203 for the $\alpha-/ \beta$-esterases loci and malate dehydrogenase/acid phosphatase loci, respectively. According to this, the estimates of gene flow were high $\left(\mathrm{N}_{\mathrm{m}}=18.008\right.$ and 10.203). The pattern of allele migration or the exchange of alleles between populations may have contributed to maintain homogeneity between the two populations of $C$. canadensis and C. bonariensis.

The frequency of alleles in both populations is very homogenous, i.e., the distribution of alleles for all loci analyzed showed no preferential distribution in any of the evaluated populations. Estimates calculated in the present study lead to the proposition of no reproductive isolation between species of C. bonariensis and C. canadensis. Lack of genetic differentiation may indicate exchange of alleles between both populations, what is reasonable to occur as long as plants share the same space for long periods of time.

When reproductive aspects of these species are considered, a greater differentiation should be expected, since both species of Conyza are self-compatible and apparently are not pollinated by insects, suggesting the occurrence of autogamy or wind pollination (Thebaud et al., 1996). Conyza canadensis is self-compatible (Mulligan and Findlay, 1970); pollen is released before capitulum full opening, suggesting self-pollination, although insects visit open flowers (Smisek, 1995). However, when paraquat-resistant plants were used as markers, the average level of self-crossing within a population of C. canadensis was only $4 \%$ (ranging from 1.2 to $14.5 \%$ ). Therefore, besides self-crossing not to be the most frequent reproduction form for these species, a second way to explain the low differentiation between them is the ability to develop hybridization between $C$. canadensis and other species in Conyza genus, specially $C$. sumatrensis and C. bonariensis, since they usually grow in associated populations and occur on a frequent basis (Thebaud and Abbott, 1995). Small differences for genetic variation among different populations may indicate a large spatial dispersion or a recent disturbance in genetic variation associated to human action (Allendorf and Luikart, 2007).

Concurrent occurrence of spatial coexistence for long periods of time, ability of hybridization and populations frequently disturbed by human interference may determine the low level of genetic differentiation between the two species of Conyza. Small-scale disturbances such as the continuous use of herbicides can promote an increase in spatial homogeneity. The increased selection pressure imposed by traditional weed management tools has contributed to selection of herbicide-resistant biotypes (Holt and LeBaron, 1990) and may be an important component to determine how the populations are genetically structured.

The deficiency of heterozygous plants in both populations of Conyza was also evident by positive values of $F_{I S}\left(F_{I S}=0.1484\right.$ for $\alpha$ - and $\beta$-esterases and $F_{I S}=0.32$ for $\mathrm{MDH}$ and ACP). Positive values of $\mathrm{F}_{\mathrm{IS}}$ indicate a deficit of heterozygous or excess of homozygous plants. This 
event could be the result of selection pressure imposed by frequent application of herbicides in soybean fields or of self pollination, which is described for these species. Significant values of $\mathrm{F}_{\mathrm{IT}}\left(\mathrm{F}_{\mathrm{IT}}=0.1607\right.$ for $\mathrm{\alpha}$ - and $\beta$-esterases and $\mathrm{F}_{\mathrm{IT}}=0.3363$ for $\mathrm{MDH}$ and $\left.\mathrm{ACP}\right)$ indicate that frequent self-crossing or nonrandom-crossing should have a fundamental role in shaping the genetic structure of $C$. bonariensis and $C$. canadensis populations. On the other hand, the high heterozygosity found in populations of $C$. bonariensis and C. canadensis may indicate that these plant populations have a substantial amount of adaptive genetic variations, and that these variations may be enough for them to escape of the eventual effects of a control agent.

Levels of interpopulational genetic diversity in species C. bonariensis and C. canadensis may be evaluated based on values of Nei's genetic identity (I) of both populations. I values also demonstrated a very small genetic differentiation between the two species of Conyza. The degree of genetic divergence may be used to develop crop and weed management policies to provide more effective control of $C$. bonariensis and C. canadensis. For populations of these two species with high genetic identity values, similar weed control strategies may be adopted.

This research on genetic diversity in species of Conyza was important since no studies could be found in the scientific literature. So far, most available information have been focused on reports of resistant populations, on aspects related to herbicide efficiency in its control and on elucidating mechanisms that promote herbicide resistance in this genus. Such studies are important since herbicide resistance has already been reported in six countries for $C$. bonariensis and in 13 countries for C. canadensis (Heap, 2010). Biotypes of both species have also been reported as resistant to glyphosate in Brazil by Christoffoleti et al. (2006), Montezuma et al. (2006), Moreira et al. (2007), Vargas et al. (2007), and confirmed by Lamego and Vidal (2008). Developing knowledge on genetic diversity and population structure is important to orientate weed management programs, leading to differential or specific forms of control, making them more effective to control species in Conyza genus.

The analysis of $a-$ and $\beta$-esteases, malate dehydrogenase and acid phosphatase isozymes revealed high genetic diversity in C. bonariensis and C. canadensis species, and limited genetic differentiation between them, indicating that it may be possible to develop similar weed control mechanisms and strategies (type and doses of herbicides, for instance) for both species. Based on our results, there is an expectation that weed control approaches developed for one species should also be effective for the other species, considering the limited genetic differentiation detected between them.

\section{References}

Adahl, E.; Lundberg, P. \& Jonzan, N. (2006). From climate change to population change: the need to consider annual life cycles. Global Change Biology, v. 12, n. 9 (September), p. 1627-1633. ISSN: 1365-2486.

Al-Samman, N.; Martin, A. \& Puech, S. (2001). Inflorescence architecture variability and its possible relationship to environment or age in a Mediterranean species, Euphorbia nicaeensis All. (Euphorbiaceae). Botanical Journal of the Linnean Society, v. 136, n. 2 (February), p. 99-105. ISSN: 1095-8339. 
Alcorta, M.; Fidelibus, M.W.; Steenwerth, K.L. \& Shrestha, A. (2011). Effect of vineyard row orientation on growth and phenology of glyphosate-resistant and glyphosatesusceptible horseweed (Conyza canadensis). Weed Science, v. 59, n. 1 (January-March), p. 55-60. ISSN: 1550-2759.

Allendorf, F.W. \& Luikart, G. (2007). Conservation and the genetics of populations. Blackwell Publishing Maden, Massachusetts, 642p. ISBN: 9781405121453.

Andersen, M.C. (1993). Diaspore morphology and seed disperal in several wind-dispersed Asteraceae. American Journal of Botany, v. 80, n. 5 (May), p. 487-492. ISSN: 0002-9122.

Archibold, O.W. (1981). Buried viable propagules in native prairie and adjacent agricultural sites in central Saskatchewan. Canadian Journal of Botany, v. 59, n. 5 (May), p. 701706. ISSN: 1916-2804.

Barnes, J.; Johnson, B.; Gibson, K. \& Weller, S. (2004). Crop rotation and tillage system influence late-season incidence of giant ragweed and horseweed in Indiana soybean. In: <http://www.plantmanagementnetwork.org/pub/cm/brief/2004/late/>. April, 19, 2010.

Barroso, G.M. (1984). Sistemática de angiospermas do Brasil. Universidade Federal de Viçosa, Viçosa, vol. 2, 377p. ISBN: 85-7269-127-8.

Betts, K.J.; Ehlke, N.J.; Wyse, D.L.; Gronwald, J.W. \& Somers, D.A. (1992). Mechanism of inheritance of diclofop resistance in italian ryegrass (Lolium multiflorum). Weed Science, v. 40, n. 2 (April-June), p. 184-189. ISSN: 1550-2759.

Bhowmik, P.C. \& Bekech, M.M. (1993). Horseweed (Conyza canadensis) seed production, emergence, and distribution in no-tillage and conventional tillage corn (Zea mays). Agronomy, v. 1, n.1, p. 67-71. ISSN: 0065-2113.

Bruce, J.A. \& Kells, J. (1990). Horseweed (Conyza canadensis) control in no-tillage soybeans (Glycine max) with preplant and preemergence herbicides. Weed Technology, v. 4, n. 4 (October-December), p. 642-647. ISSN: 0890-037X.

Buhler, D.D. \& Owen, M.D.K. (1997). Emergence and survival of horseweed (Conyza canadensis). Weed Science, v. 45, n. 1 (January- March), p. 98-101. ISSN: 1550-2759.

Burnside, O.C. (1992). Rationale for developing herbicide-resistant crops. Weed Technology, v. 6, n. 4 (October-December), p. 621-625. ISSN: 0890-037X.

Castro, H.G.; Silva D.J.H.; Ferreira, F.A. \& Ribeiro Júnior, J.I. (2002). Estabilidade da divergência genética em seis acessos de carqueja. Planta Daninha, v. 20, n.1 (January-March), p. 33-37. ISSN: 0100-8358.

Chemale, V.M. \& Fleck, N.G. (1982). Avaliação de cultivares de soja (Glycine max (L.) Merrill) em competição com Euphorbia heterophylla L. sob três densidades e dois períodos de ocorrência. Planta Daninha, v.5, n. 2 (April-June), p. 36-45. ISSN: 01008358.

Cronquist, A. (1981). An integrated system of classification of flowering plants. New York, Columbia University Press. 1262p. ISBN 0-231-03880-1.

Dauer, J.T.; Mortensen, D.A. \& Humston, R. (2006). Controlled experiments to predict horseweed (Conyza canadensis) dispersal distances. Weed Science, v. 54, n. 3 (May), p. 484-489. ISSN: 1550-2759.

DeGennaro, F.P. \& Weller, S.C. (1984). Differential susceptibility of field bindweed (Convolvulus arvensis) biotypes to glyphosate [Indiana]. Weed Science, v. 32, n. 3 (May), p. 472-476. ISSN: 1550-2759. 
Frankton, C. \& Mulligan, G.A. (1987). Weeds of Canada. Toronto: NC, Pr. 217p. ISBN-10: 1550210165.

Frigo, M.J.; Mangolin, C.A.; Oliveira, R.S.J. \& Machado, M.F.P.S. (2009). Esterase polymorphism for analysis of genetic diversity and structure of wild poinsettia (Euphorbia heterophylla) populations. Weed Science, v. 57, n. 1 (January), p. 54-60. ISSN: 1550-2759.

Gazziero, D.L.P.; Brighenti, A.M.; Maciel, C.D.G.; Christoffoleti, P.J.; Adegas, F.S. \& Voll, E. (1998). Resistência de amendoim-bravo aos herbicidas inibidores da enzima ALS. Planta Daninha, v. 16, n. 2 (December), p. 117-125. ISSN: 0100-8358.

Gómez, C. \& Espadaler, X. (1998). Seed dispersal curve of a Mediterranean myrmecochore: Influence of ant size and the distance to nests. Ecological Research, v. 13, n. 3 (October), p. 347-352. ISSN: 1440-1703.

Goolsby, J.A.; De Barro, P.J.; Makinson, J.R.; Pemberton, R.W.; Hartley, D.M. \& Frohlich, D.R. (2006). Matching the origin of an invasive weed for selection of a herbivore haplotype for a biological control program. Molecular Ecology, v. 15, n. 1 (January), p. 287-297. INSS: 1365-294X.

Grombone-Guaratini, M.T.; Silva-Brandão, K.L.; Solferini, V.N.; Semir, J. \& Trigo, R. (2005). Sesquiterpene and polyacetylene profile of the Bidens pilosa complex (Asteraceae: Heliantheae) from southeast of Brazil. Biochemical Systematics and Ecology, v. 33, n. 10 (July-September), p. 479-486. ISSN: 0305-1978.

Hamrick, J.L.; Linhart, Y.B. \& Mitton, J.B. (1979). Relationship between life history characteristics and electrophoretically-detectable genetic variation in plants. Annual Review of Ecology and Systematics, v. 10, p. 173-200. ISSN: 0066-4162.

Hanf, M. (1983). The arable weeds of Europe with their seedlings and seeds. BASF Aktiengesellschaft, Ludwigshafen, Germany. 494p. ASIN: B0007B15JC.

Harper, J.L. (1956). The evolution of weeds in relation to resistance to herbicides. British Crop Protection Conference, v. 1, n. 1, p.179-188. ISSN: 0144-1612.

Heap, I. (2010). International survey of herbicide-resistant weeds. In: $<$ http://www.weedscience.com>. February, 20, 2010.

Hilton, H.W. (1957). Herbicide tolerant strains of weeds. HSCPA Annual Report, p.66.

Holm, L.; Doll, J.; Holm, E.; Pancho, J. \& Herberger, J. (1997). Conyza canadensis (L.) Cronq. (syn. Erigeron canadensis L.). World Weeds: Natural Histories and Distributions. John Wiley and Sons, Inc. Toronto, (March), p. 226-235. ISBN: 978-0-471-04701-8.

Holt, J.S. \& LeBaron, H.M. (1990). Significance and distribution of herbicide resistance. Weed Technology, v. 4, n. 2 (July), p. 141-149. ISSN: 0890-037X.

Hufbauer, R. (2004). Population genetics of invasions: Can we link neutral markers to management? Weed Technology, v. 18, n. 4 (December), p. 1522-1527. ISSN: 0890037X.

Ingrouille, M. (1992). Diversity and evolution of land plants. London, Chapman \& Hall, 340p. ISBN: 04124423029780412442308.

Joly, A.B. (1998). Botânica: Introdução à taxonomia vegetal. 12th. Ed. São Paulo. Companhia Editora Nacional, 778p. ISBN: 8504002314.

Kissmann, K.G. \& Groth, D. (1992). Plantas infestantes e nocivas. São Paulo: Basf, 798p. ISBN: 8588299038.

Kissmann, K.G. \& Groth, D. (1999). Plantas infestantes e nocivas. 2th. Ed. São Paulo: Basf, v. 2, 978p. ISBN: 85-88299-02-X. 
Lamego, F.P. \& Vidal, R.A. (2008). Resistência ao glyphosate em biótipos de Conyza bonariensis e Conyza canadensis no estado do Rio Grande do Sul, Brasil. Planta Daninha, v. 26, n.2 (April-June), p. 467-471. ISSN: 0100-8358.

Lazaroto, C.A.; Fleck, N.G. \& Vidal, R.A. (2008). Biologia e ecofisiologia de buva (Conyza bonariensis e Conyza canadensis). Ciência Rural, v. 38, n. 3 (Maio-Junho), p. 852-860. ISSN: 0103-8478.

Lehoczki, E.; Laskay, G.; Pölös E. \& Mikulás J. (1984). Resistance to triazine herbicides in horseweed (Conyza canadensis). Weed Science, v. 32, n. 4 (Julio) p. 669-674. ISSN: 0043-1745.

Leroux, G.D.; Benoît, D-L. \& Banville, S. (1996). Effect of crop rotations on weed control, Bidens cernua and Erigeron Canadensis populations, and carrot yields in organic soils. Crop Protection, v. 15, n. 2 (March), p. 171-178. ISSN: 0261-2194.

Loux, M.; Stachler, J.; Johnson, B.; Nice, G.; Davis, V. \& Nordby, D. (2004). Biology and management of horseweed. In: <http://www.ipm.uiuc.edu/pubs/horseweed.pdf>. April, 17, 2010.

Loux, M.; Stachler, J.; Johnson, B.; Nice, G.; Davis, V. \& Nordby, D. (2009). Biology and management of horseweed. The glyphosate, weeds, and crop series, Purdue University (Purdue Extension publication number ID-32), 11p. ISBN: 978-0-19-532694-9.

Machado, M.F.P.S.; Prioli, A.J. \& Mangolin, C.A. (1993). Malate dehydrogenase (MDH; EC 1.1.1.37) isozymes in tissues and callus cultures of Cereus peruvianus (Cactaceae). Biochemical Genetics, v. 31, n. 3/4 (April), p. 167-172. ISSN: 0006-2928.

Mangolin, C.A.; Prioli, A.J. \& Machado, M.F.P.S. (1997). Isozyme variability in plants regenerated from calli of Cereus peruvianus (Cactaceae). Biochemical Genetics, v. 35, n. 5/6 (June), p. 189-204. ISSN: 0006-2928.

Mattielo, R.R.; Ronzeli Júnior, P. \& Puríssimo, C. (1999). Mecanismos de resistência: fatores biológicos, agronômicos e genéticos. In: Curso de manejo da resistência de plantas daninhas aos herbicidas, 2. Ponta Grossa. Anais. Ponta Grossa: AECG, p. 27-40.

Meschede, D.K.; Oliveira Jr., R.S.; Constantin, J. \& Scapim, C.A. (2002). Período crítico de interferência de Euphorbia heterophylla na cultura da soja sob baixa densidade de semeadura. Planta Daninha, v. 20, n. 3 (July-September), p. 381-387. ISSN: 0100-8358.

Moreira, M.S.; Nicolai, M.; Carvalho, S.J.P. \& Christoffoleti, P.J. (2007). Resistência de Conyza canadensis e C. bonariensis ao herbicida glyphosate. Planta Daninha, v. 25, n. 1 (January-March), p. 157-164. ISSN: 0100-8358.

Mulligan, G.A. \& Findlay, J.N. (1970). Reproductive systems and colonization in Canadian weeds. Canadian Journal of Botany, v. 5, n. 5 (May), p. 859-860. ISSN: 0008-4026.

Nandula, V.K.; Eubank, T.W.; Poston, D.H.; Koger, C.H. \& Reddy, K.N. (2006). Factors affecting germination of horseweed (Conyza canadensis). Weed Science, v. 54, n. 5 (September), p. 898-902. ISSN: 0043-1745.

Narbona, E.; Arista, M. \& Ortiz, P.L. (2005). Explosive seed dispersal in two perennial mediterranean Euphorbia species (Euphorbiaceae). American Journal of Botany, v. 92, n. 3 (March), p. 510-516. ISSN: 1537-2197.

Nissen, S.J.; Masters, R.A.; Lee, D.J. \& Rowe, M.L. (1992). Comparison of restrictionfragment-length-polymorphisms in chloroplast DNA of 5 leafy spurge (Euphorbia spp) accessions. Weed Science, v. 40, n. 1 (March), p. 63-67. ISSN: 0043-1745.

Oliveira Jr, R.S.; Constantin, J.; Blainski, E. \& Oliveira Neto, A.M. (2010). Fall application as alternative for glyphosate-resistant biotypes of Conyza sp. control in Paraná 
(southern Brazil). In: Pan-American Weed Resistance Conference, 2010, Miami. Annals. Miami: Bayer Crop Science, v. 1 (January 2010).

Orasmo, G.R.; Oliveira-Collet, S.A.; Lapenta, A.S. \& Machado, M.F.P.S. (2007). Biochemical and Genetic Polymorphisms for Carboxylesterase and Acetylesterase in Grape Clones of Vitis vinifera L. (Vitaceae) Cultivars. Biochemical Genetics, v. 45, n. 9-10 (October), p. 663-670. ISSN: 15734927.

Owen, M.D.K. (2001). World maize/soybean herbicide resistance. In: Powles, S.B.; Shander, D.L. Herbicide resistance and world grains. Boca Raton, CRC Press, p. 101-164. ISBN/ISSN: 0849322197.

Park, K.; Jung, H.; Ahn, B.; Lee, K. \& Kim, J. (1999). Genetic and morphological divergence in Korean Euphorbia ebracteolata (Euphorbiaceae). Korean Journal of Plant Taxonomy, v. 29, p. 249-262. ISSN: 1225-8318.

Park, K.R. (2004). Comparisons of allozyme variation of narrow endemic and widespread species of Far East Euphorbia (Euphorbiaceae). Botanical Bulletin of Academia Sinica, v. 45, n. 3 (July), p. 221-228. ISSN: 1817-406X.

Pereira, A.J.; Vidigal-Filho, P.S.; Lapenta, A.S. \& Machado, M.F.P.S. (2001). Differential esterase expression in leaves of Manihot esculenta, Crantz infected with Xanthomonas axonopodis pv. manihotis. Biochemical Genetics, v. 39, n. 9/10 (October), p. 289-296. ISSN: 0006-2928.

Pitelli, R.A. (1985). Interferência de plantas daninhas em culturas agrícolas. Informativo Agropecuária, v. 11, n. 126 (March), p. 16-27. ISSN: 0325-2116.

Ponchio, J.A.R. (1997). Resistência de Bidens pilosa L. aos herbicidas inibidores da enzima acetolactato sintase. Tese (Doutorado) - Escola Superior de Agricultura "Luiz de Queiroz", Universidade de São Paulo, Piracicaba, 138p.

Powles, S.B. \& Holtum, J.A.M. (1994). Herbicide resistance in plants: Biology and biochemistry. Boca Raton, 353p. ISBN: 0873717139.

Regehr, D.L. \& Bazzaz, F.A. (1979). The population dynamics of Erigeron Canadensis, a sucessional winter annual. Journal of Ecology, v. 67, n. 3 (November), p. 923-933. ISSN: 1365-2745.

Resende, A.G.; Machado, M.F.P.S. \& Vidigal-Filho, P.S. (2004). Esterase polymorphism marking cultivars of Manihot esculenta, Crantz. Brazilian Archives of Biology and Technology, v. 47, n. 3 (June), p. 347-353. ISSN: 1516-8913.

Rollin, M.J. \& Tan, D. (2004). Fleabane: first report of glyphosate resistant flax-leaf fleabane from western Darling Downs. In:

$<$ http://www.weeds.rc.org.au/documents/fleabane_preceedings\%20_mar_04.pdf $>$ June, 26, 2010.

Rouleau, E. \& Lamoureux, G. (1992). Atlas of the vascular plants of the island of Newfoundland and of the islands of Saint Pierre et Miguelon. Quebec: Group Fleurbec, p. 777. ISBN: 29201741269782920174122.

Rowe, M.L.; Lee, D.J.; Bowditch, B.M. \& Masters, R.A. (1997). Genetic variation in North American leafy spurge (Euphorbia esula) determined by DNA markers. Weed Science, v. 45, n. 4 (December), p. 446-454. ISSN: 0043-1745.

Slotta, T.A.B. (2008). What we know about weeds: insights from genetic markers. Weed Science, v. 56, n. 2 (September), p. 322-326. ISSN: 0043-1745.

Smisek, A.J.J. (1995). The evolution of resistance to paraquat in populations of Erigeron Canadensis L. Master Thesis. University of Western Ontario, London, Ontário, 102p. 
Souza, F.P.; Machado, M.F.P.S. \& Resende, A.G. (2000). Esterase isozymes for the characterization of "unnamed" cassava cultivars (Manihot esculenta, Crantz). Acta Scientiarum Biological Sciences, v. 22, n. 1, p. 275-280. ISSN: 1679-9283.

Steinmaus, S.J.; Prather, T.S. \& Holt, J.S. (2000). Estimation of base temperatures for nine weed species. Journal of Experimental Botany, v. 51, n. 343 (February), p. 275-286. ISSN: 1460-2431.

Sterling, T.M.; Thompson, D.C. \& Abbott, L.B. (2004). Implications of invasive plant variation for weed management. Weed Technology, v. 18, n.4 (December), p. 13191324. ISSN: 0890-037X.

Suda, C.N.K. (2001). Hidrolases da parede celular em sementes de Euphorbia heterophylla L. durante a germinação e desenvolvimento da plântula. Doctor Thesis Universidade de São Paulo, Ribeirão Preto.

Switzer, C.M. (1957). The existence of 2,4-D resistant strains of wild carrot (Daucus carota). Meeting of the NEWSS, Proceedings, NEWSS, p. 315-318.

Thebaud, C. \& Abbott, R.J. (1995). Characterization of invasive Conyza species (Asteraceae) in Europe: quantitative trait and isozyme analysis. American Journal of Botany, v. 82, n. 2 (February), p. 360-368. ISSN: 0002-9122.

Thebaud, C.; Finzi, A.C.; Affre, L.; Debussche, M. \& Escarre, J. (1996). Assessing why two introduced Conyza differ in their ability to invade Mediterranean old fields. Ecology, v. 77, n. 3 (April), p. 791-804. ISSN: 0012-9658.

Trezzi, M.M.; Felippi, C.L.; Mattei, D.; Silva, H.L.; Nunes, A.L.; Debastiani, C.; Vidal, R.A. \& Marques, A. (2005). Multiple resistance of acetolactate synthase and protoporphyrinogen oxidase inhibitors in Euphorbia heterophylla biotypes. Journal Environmental Science and Health- Part B, v. 40, n. 2 (February), p. 101-109. ISSN: 0360-1234.

Trezzi, M.M.; Portes, E.D.S.; Silva, H.L.; Gustman, M.S.; Da Silva, R.P. \& Franchin, E. (2009). Morphophysiological characteristics of Euphorbia heterophylla biotypes resistant to different herbicide action mechanisms. Planta Daninha, v. 27, number especial (December), p. 1075-1082. ISSN: 0100-8358.

Van Gessel, M.J. (2001). Glyphosate-resistant horseweed from Delaware. Weed Science, v. 49, n. 4 (December), p. 703-705. ISSN: 1939-747X.

Vargas, L.; Bianchi, M.A.; Rizzardi, M.A.; Agostinetto, D. \& Dal Magro, T. (2007). Conyza bonariensis biotypes resistant to the glyphosate in southern Brazil. Planta Daninha, v. 25, n. 3 (September), p. 573-578. ISSN: 0100-8358.

Vidal, R.A. \& Merotto Jr., A. (1999). Resistência de amendoim bravo (Euphorbia heterophylla L.) aos herbicidas inibidores da enzima acetolactato sintase. Planta Daninha, v. 17, n. 3 (December), p. 367-373. ISSN: 0100-8358.

Vidal, R.A. \& Merotto Jr, A. (2001). Herbicidas inibidores de ACCase. Herbicidologia. In Vidal, R.A., Merotto Jr, A.(Eds.). Porto Alegre p.15 - 24. ISBN: 2000050447006.

Vidal, R.A.; Trezzi, M.M.; De Prado, R.; Ruiz-Santaella, J.P. \& Vila-Aiub, M.M. (2007). Glyphosate resistant biotypes of wild poinsettia (Euphorbia heterophylla L.) and its risk analysis on glyphosate-tolerant soybeans. International Journal of Food, Agriculture and Environment, v. 2, n. 2 (February), p. 265-269. ISSN: 1459-0263.

Vidal, R.A. \& Winker, L.M. (2002). Resistência de plantas daninhas: seleção ou indução à mutação pelos herbicidas inibidores de acetolactato sintase (ALS). Pesticidas: Revista de Ecotoxicologia e Meio Ambiente, v. 12, n. 0 (Janeiro-Dezembro), p. 31-42. ISSN: 19839847. 


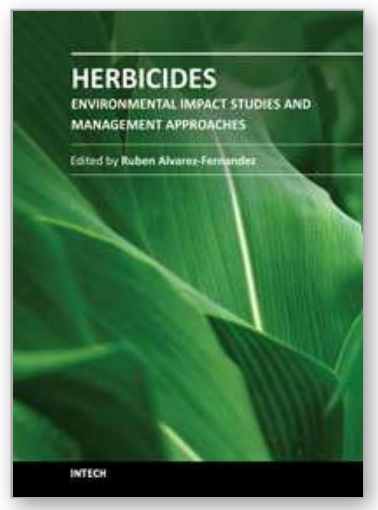

\section{Herbicides - Environmental Impact Studies and Management Approaches}

Edited by Dr. Ruben Alvarez-Fernandez

ISBN 978-953-307-892-2

Hard cover, 248 pages

Publisher InTech

Published online 20, January, 2012

Published in print edition January, 2012

Weeds severely affect crop quality and yield. Therefore, successful farming relies on their control by coordinated management approaches. Among these, chemical herbicides are of key importance. Their development and commercialization began in the 1940's and they allowed for a qualitative increase in crop yield and quality when it was most needed. This book blends review chapters with scientific studies, creating an overview of some the current trends in the field of herbicides. Included are environmental studies on their toxicity and impact on natural populations, methods to reduce herbicide inputs and therefore overall non-target toxicity, and the use of bioherbicides as natural alternatives.

\section{How to reference}

In order to correctly reference this scholarly work, feel free to copy and paste the following:

Claudete Aparecida Mangolin, Rubem Silvério de Oliveira Junior and Maria de Fátima P.S. Machado (2012). Genetic Diversity in Weeds, Herbicides - Environmental Impact Studies and Management Approaches, Dr. Ruben Alvarez-Fernandez (Ed.), ISBN: 978-953-307-892-2, InTech, Available from:

http://www.intechopen.com/books/herbicides-environmental-impact-studies-and-managementapproaches/genetic-diversity-and-structure-of-weed-plant-populations

\section{INTECH}

open science | open minds

\section{InTech Europe}

University Campus STeP Ri

Slavka Krautzeka 83/A

51000 Rijeka, Croatia

Phone: +385 (51) 770447

Fax: +385 (51) 686166

www.intechopen.com

\section{InTech China}

Unit 405, Office Block, Hotel Equatorial Shanghai

No.65, Yan An Road (West), Shanghai, 200040, China

中国上海市延安西路65号上海国际贵都大饭店办公楼 405 单元

Phone: +86-21-62489820

Fax: +86-21-62489821 
(C) 2012 The Author(s). Licensee IntechOpen. This is an open access article distributed under the terms of the Creative Commons Attribution 3.0 License, which permits unrestricted use, distribution, and reproduction in any medium, provided the original work is properly cited. 